WARD 2000.20
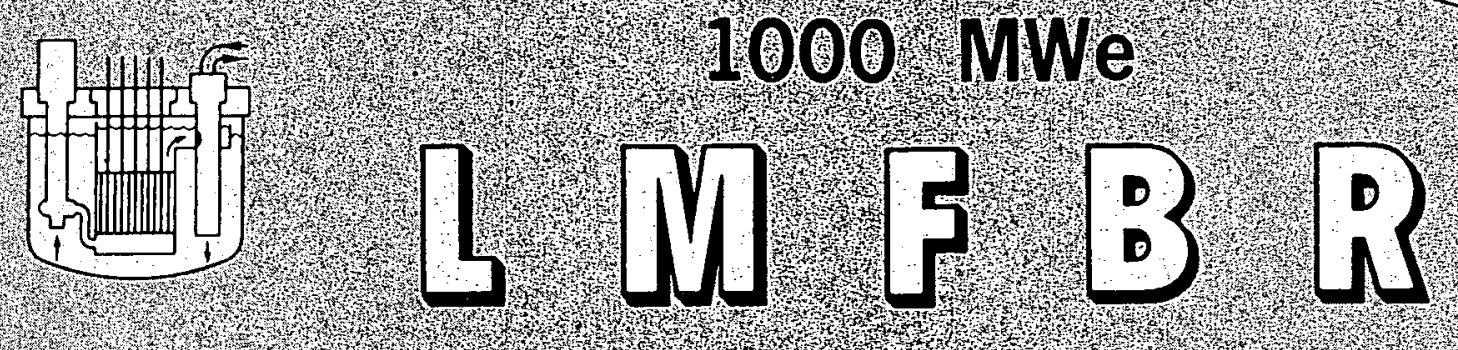

C2L Liquid Metal Tast Breeder Reactor

\title{
FOLLOW ON STUDY
}

\section{WESTINGHOUSE ELECTRIC \\ TASK I REPORT}

\section{Topical Report}

\section{Moisture Separation or Steam}

Reheat vs. Sodium Reheat

Plant Cycle Technical and Economic Evaluation 


\section{DISCLAIMER}

This report was prepared as an account of work sponsored by an agency of the United States Government. Neither the United States Government nor any agency Thereof, nor any of their employees, makes any warranty, express or implied, or assumes any legal liability or responsibility for the accuracy, completeness, or usefulness of any information, apparatus, product, or process disclosed, or represents that its use would not infringe privately owned rights. Reference herein to any specific commercial product, process, or service by trade name, trademark, manufacturer, or otherwise does not necessarily constitute or imply its endorsement, recommendation, or favoring by the United States Government or any agency thereof. The views and opinions of authors expressed herein do not necessarily state or reflect those of the United States Government or any agency thereof. 


\section{DISCLAIMER}

Portions of this document may be illegible in electronic image products. Images are produced from the best available original document. 


\section{LEGAL NOTICE}

This report was prepared as an account of Government sponsored work. Nelther the United States, nor the Commission, nor any person acting on behalf of the Commission:

A. Makes any warranty or representation, expressed or implied, with respect to the accuracy, completeness, or usefulness of the Information contained in this report, or that the use of any information, apparatus, method. or process disclosed in this report may not infringe privately ouned righta; or

B. Assumes any liabllities with respect to the use of, or for damages resulting from the use of any information, apparatus, method, or process diaclosed in this report.

As used in the above. "person acting on behall of the Commlssion" Includes any employee or contractor of the Commission, or employee of such contractor, to the extent that such employee or contractor of the Commission, or employee of such contractor prepares, disseminates, or provides access to, any information pursuant to his employment or contract with the Commission, or his employment with such contractor.

This report has been reproduced directly from the best available copy.

Printed in USA. Price $\$ 3.00$. Available from the Clearinghouse for Federal Scientific and Technical Information, National Bureau of Standards, U. S. Department of Commerce, Springfield, Virginia 22151. 


\title{
LEGAL NOTICE
}

This report was prepared as an account of Government sponsored work. Neither the United The Commission, nor any person acting on behalf of the Commission:

A.

A. Makes any waranty or the use racy, completeness, or useflus, method, or process disclosed in this report may not infringe of any information, apparatus

privately owned rights; or B. Assumes any liabilities with respect to the wess disclosed in this report.

use of any information, apparatus, method, or process disclosed in thission" includes any em-

As used in the above. "person acting on behalf of the Commission" includes any employee or contractor of the Commission, or employee of such contractor. to the ex preperes such employee or contractor of the Commission, or employee of such conloyment prentract disseminates, or provides access to, any information pursuant wo bs employment with the Commission, or his employment with such contractor.

WARD-2000-20

REACTOR TECHNOLOGY (TID-4500)

1000 MWe FAST BREEDER REACTOR FOLLOW-ON STUDY

MOISTURE SEPARATION OR STEAM REHEAT

VS

SODIUM REHEAT PLANT CYCLE

TECHNICAL AND ECONOMIC EVALUATION

by

I. M. Keyfitz

Thermal Systems

APPRoved: BOC Kunoan

W. E. Gunson - Manager

Thermal Systems
APPROVED :

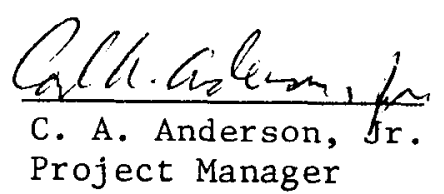

Prepared for Argonne National Laboratory

Under Contract No. 31-109-38-200

\author{
April, 1968 \\ Reissued January, 1969 \\ Westinghouse Electric Corporation \\ Advanced Reactors Division \\ P. 0. Box 158 \\ Madison, Pennsylvania 15663
}

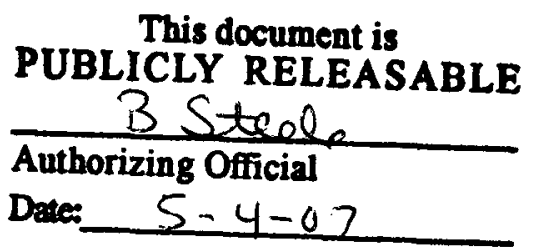


Prices and costs given herein are for estimating purposes only. They should not be considered as Westinghouse prices and quotations. 
TABLE OF CONTENTS

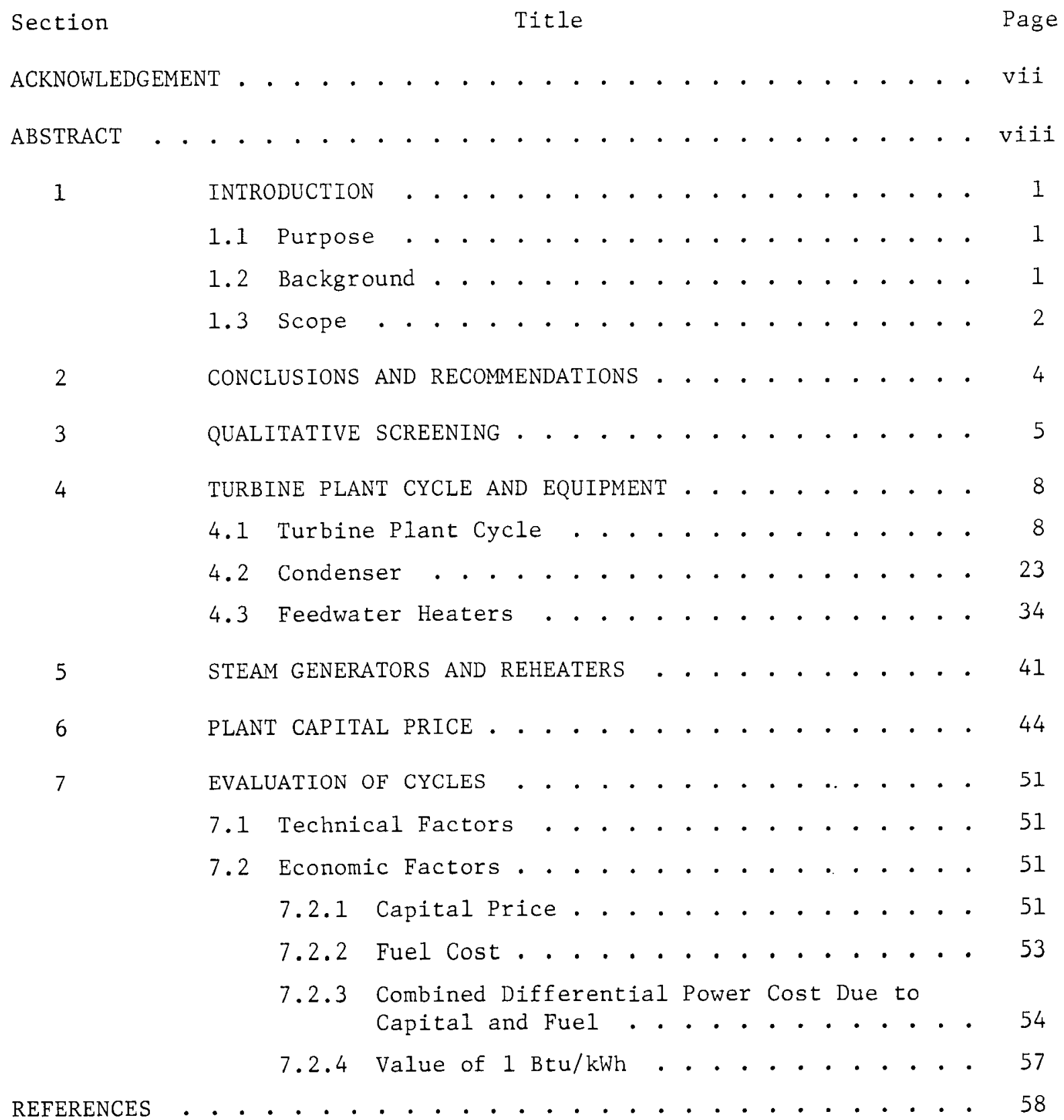




\section{LIST OF ILLUSTRATIONS}

Figure

1

2
Title

Page

Variation of Heat Rate with Temperature and Pressure

Moisture Separation Cycle, Turbine Plant, Detailed Heat Balance

Moisture Separation Turbine

Dimensions, Moisture Separation Turbine

Layout Moisture Separators

Heat Balance Schematic, Sodium Reheat

Sodium Reheat Turbine, Shaft A

Dimensions, Sodium Reheat Turbine, Shaft A

Sodium Reheat Turbine, Shaft B

Dimensions, Sodium Reheat Turbine, Shaft B

Mollier Diagram, Moisture Separation and Sodium Reheat

Comparison of Turbine Plant Net Heat Rates for Various Throttle Steam Conditions

Base Plant Condenser

Reheat Plant Condenser

28

Air Ejector

30

Priming Ejector

31

Circulating Water Pump (CT-20207)

32

Circulating Water Pump (CT-20208)

33

Condensate Pump

35

Base Plant Hemispherical Head High Pressure Feedwater Heater $(1,2,3,4)$

Base Plant Hemispherical Head High Pressure Feedwater Heater $(5,6,7)$

Reheat Plant Hemispherical Head High Pressure Feedwater Heater $(1,2,3,4)$ 


\section{LIST OF ILLUSTRATIONS (Cont)}

Figure

23

24

25
Title

Reheat Plant Hemispherical Head High Pressure

Feedwater Heater $(5,6,7)$

Differential Power Cost Envelope for Sodium ReheatMoisture Separation

Differential Power Cost Envelope for Sodium Reheat-

Moisture Separation as a Function of $\Delta$ Heat Rate
40 55

Page

56 


\section{LIST OF TABLES}

Table

Title

Page

1 Major Work Areas for Steam Cycle Selection 3

2 Possible Steam Cycles 5

3 Turbine Plant Functional Specifications 8

4 Comparison of Moisture Separation and Reheat Cycles 24

5 Condenser Parameters 26

6 Circulating Water Pump Parameters 29

7 Condensate Pump Parameters 34

8 Sodium-Heated Steam Generator and Reheater Parameters 42

9 Capital Items Affected by Moisture Separation or Sodium Reheat Cycles

10 Differential Power Costs Due to Capital Reheat Minus Moisture Separation, $\Delta \mathrm{f}$

11 Differential Power Cost Due to Fuel 54

12 Differential Power Cost for Reheat-Moisture Separation Plant 


\section{ACKNOWLEDGEMENT}

This evaluation utilized the efforts of several groups and many individuals. The principal contributors are:

United Engineers and Constructors, Inc., U-E

Westinghouse Large Turbine Divisions, WLTD

Westinghouse Heat Transfer Division, WHTD

Westinghouse Advanced Reactors Division, WARD
J. H. Crowley

C. L. Newman

H. L. R. Newbold

H. A. Langston

S. W. W. Mitchell

J. Bushey

A. R. Giardina

M. Gross

G. F. Pierson

J. Wasko 


\begin{abstract}
An evaluation of a moisture separation or steam reheat cycle versus a sodium reheat cycle for a nominal 1000-MWe Sodium-Cooled, Fast Breeder Reactor verifies that,from both a technical and economic viewpoint, moisture separation or steam reheat is superior to sodium reheat. The economic advantage is estimated at from 0.014 to $0.06 \mathrm{mills} / \mathrm{kWh}$ power cost, depending upon the assumed total capital price in the range of 120 to $160 \$ / \mathrm{kW}$ and the assumed fuel cost in the range of 7 to 16 cents per million Btu. Expenses incurred by the customer are not included in the total capital price.
\end{abstract}




\section{SECTION 1}

INTRODUCTION

\subsection{Purpose}

This report evaluates and selects the most suitable type of steam cycle for the 1000-MWe Fast Breeder Reactor Follow-on Study as part of Task I.

\subsection{Background}

The trend in power plant design has been to ever-higher, steam temperature and pressure conditions. The ultimate was encompassed by Philadelphia Electric Company's Eddystone Unit No. I having throttle steam at 5000 psig and $1200^{\circ} \mathrm{F}$ with double reheat to $1050^{\circ} \mathrm{F}$. Undoubtedly this is an engineering achievement of the first magnitude and plants of this type might be justified in very high fuel cost areas. However, in a fast breeder reactor, where fuel costs may be of the order of 7 to 16 cents/million Btu, such extreme steam conditions are not warranted. When additional capital costs, reduced reliability, and safety are balanced against fuel cost savings the results will probably favor a more conservative approach.

Westinghouse assisted Argonne National Laboratory in an earlier feasibility study $^{[1]}$ of a conceptual design for a nuclear steam supply system using a 10,000-MWt, sodium-cooled breeder reactor. A comparison of a sodium reheat plant with $2400 \mathrm{psig} / 900^{\circ} \mathrm{F} / 900^{\circ} \mathrm{F}$ steam and a moisture separation or steam reheat cycle at $2400 \mathrm{psig} / 900^{\circ} \mathrm{F}$ steam was made. The results indicated an apparent economic gain of less than $0.01 \mathrm{mill} / \mathrm{kWh}$ for sodium reheat. In view of additional plant complexity and reduced reliability, sodium reheat was rejected. In the current study, more detailed design information is being assembled to assist in arriving at a more substantial conclusion. 


\subsection{Scope}

Two main cases were considered in detail:

a. A moisture separation or steam reheat cycle with two sodium-heated steam generators and $2400 \mathrm{psig} / 900^{\circ} \mathrm{F}$ throttle steam

b. A sodium reheat cycle with two sodium-heated steam generators and two sodium reheaters with $2400 \mathrm{psig} / 900^{\circ} \mathrm{F} / 900^{\circ} \mathrm{F}$ steam

Each involves the work area shown in Table 1. It will also be shown how extrapolation of the results for these two cases may be applied to a more generalized result. Moreover, results are reviewed to ensure that assumptions are not made which will unintentionally bias either concept. 
TABLE 1

MAJOR WORK AREAS FOR STEAM CYCLE SELECTION

\begin{tabular}{|c|c|c|}
\hline Plant & Item & $\begin{array}{c}\text { Group } \\
\text { Performing Work }\end{array}$ \\
\hline Reactor & $\begin{array}{l}\text { 1. Reactor and heat transfer equipment } \\
\text { structure design and cost } \\
\text { 2. Steam generator specification, design, } \\
\text { and cost } \\
\text { 3. Reheater specification, design and } \\
\text { cost } \\
\text { 4. Secondary sodium piping design and } \\
\text { cost }\end{array}$ & $\begin{array}{l}\text { U-E } \\
\text { WARD \& } \underline{\text { WHTD }} \\
\text { WARD \& WHTD } \\
\text { WARD \& U-E }\end{array}$ \\
\hline Turbine & $\begin{array}{l}\text { 5. Plant specification and heat balance } \\
\text { 6. Turbine generator selection and cost } \\
\text { 7. Condenser design and cost } \\
\text { 8. Feedwater heater design and cost } \\
\text { 9. Estimate of turbine plant structure and } \\
\text { systems based on U-E study for ANL }\end{array}$ & $\begin{array}{c}\text { WARD \& WLTD } \\
\text { WLTD } \\
\text { WHTD } \\
\text { WHTD } \\
\text { U-E }\end{array}$ \\
\hline
\end{tabular}




\section{SECTION 2}

\section{CONCLUSIONS AND RECOMMENDATIONS}

The moisture separation or steam reheat cycle is superior both technically and economically to the sodium reheat cycle. Only $2400 \mathrm{psig} / 900^{\circ} \mathrm{F}$ and $2400 \mathrm{psig} /$ $900^{\circ} \mathrm{F} / 900^{\circ} \mathrm{F}$ were studied in detail; however, the conclusion is valid over a range of throttle steam pressures and temperatures due to the continuous nature of the heat rate versus pressure curve.

Sodium reheat is more complex, less reliable, and has a higher initial plant capital cost than the moisture separation or steam reheat cycle. The savings due to the lower heat rate of sodium reheat was not sufficient to balance the higher capital cost. The power cost increase of sodium reheat over moisture separation was found to vary from $0.06 \mathrm{mill} / \mathrm{kWh}$ down to $0.014 \mathrm{mill} / \mathrm{kWh}$ depending upon the fuel cost and other assumptions.

In view of the above, it is recommended that the Reference Design in Task II utilize the moisture separation cycle. Also, only moisture separation or steam reheat cycles are recommended as the basis for Task III plant optimization. 
SECTION 3

QUALITATIVE SCREENING

There are four potential cycles, all independent of steam pressure and temperature conditions. Table 2 lists these possibilities. The first three involve only differences in the turbine plant and have no especially significant effect on the secondary sodium heat-removal system of the reactor plant. The last cycle requires branching of the sodium pipe to the steam generator to supply parallel flow to the reheater.

TABLE 2

POSSIBLE STEAM CYCLES
1. Straight Expansion
2. Moisture Separation
3. Steam Reheat
4. Sodium Reheat

Straight steam expansion is impractical because the low pressure cylinder steam would have excessive moisture, thereby causing unacceptable blade erosion. Moisture separation between the high-pressure and low-pressure cylinders is possible for several, but not all combinations of steam temperatures and pressures. Steam reheat will be practical for most steam conditions. The difference between cycles 2 and 3 is less important than that between either cycle 2 or 3 and the sodium reheat cycle.

If plant gross heat rate is plotted as the ordinate and throttle pressure as the abscissa, for a given steam temperature, the resulting curve has a decreasing heat rate with increasing pressure. Figure 1 shows curves plotted ${ }^{[2]}$ for $900^{\circ} \mathrm{F} /$ $900^{\circ} \mathrm{F}$ and $1000^{\circ} \mathrm{F} / 1000^{\circ} \mathrm{F}$. 


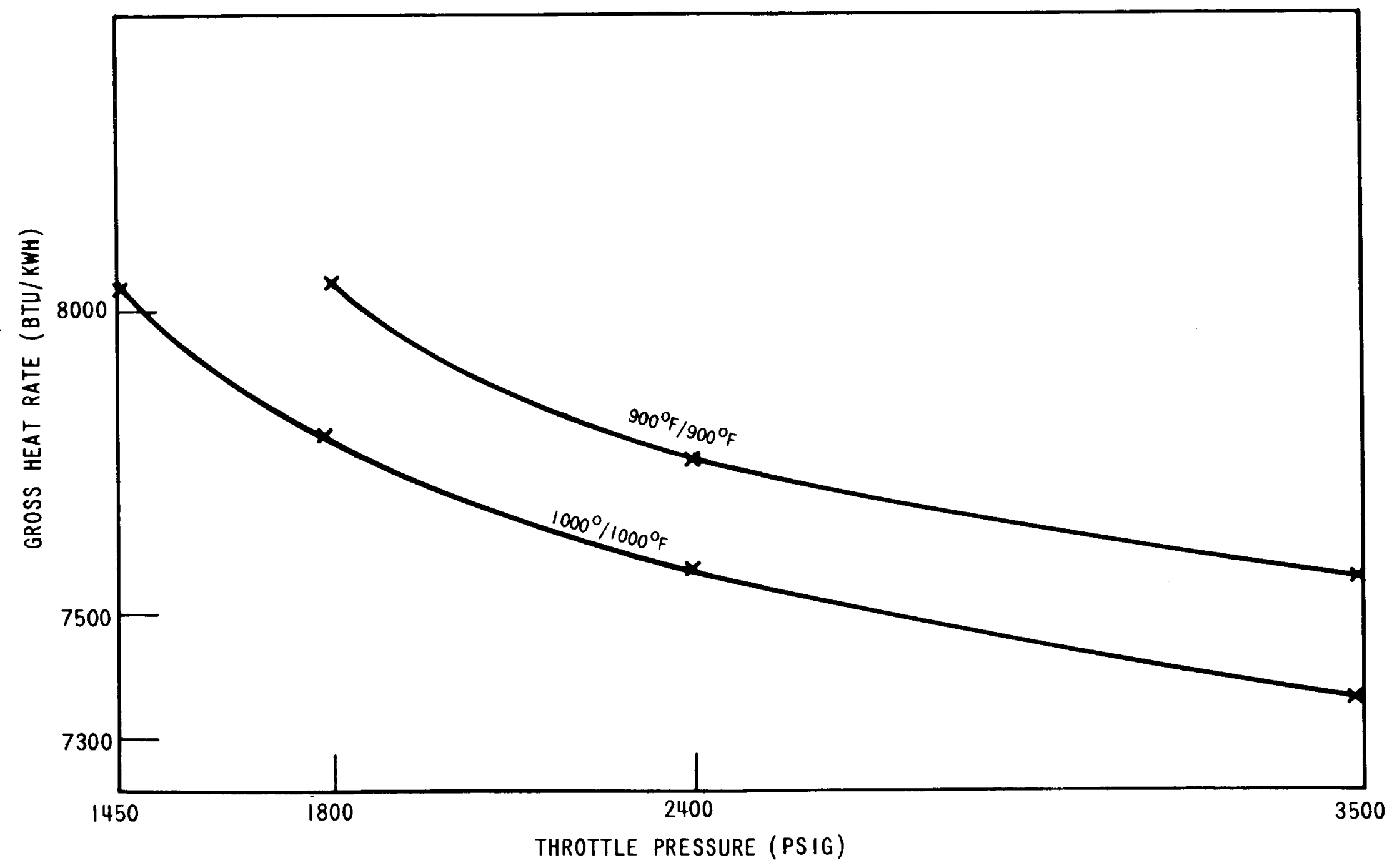

Figure 1 Variation of Heat Rate with Temperature and Pressure 
The curves are nearly parallel and it is reasoned that a family of similar curves could be drawn for many steam conditions. Therefore, in this study, differences in heat rate between moisture separation or steam reheat and sodium reheat have been assumed to be independent of pressure. Hence, the results obtained by comparing throttle steam at $2400 \mathrm{psig} / 900^{\circ} \mathrm{F}$ with moisture separation or steam reheat and steam at $2400 \mathrm{psig} / 900^{\circ} \mathrm{F} / 900^{\circ} \mathrm{F}$ should be reasonably constant, regardless of the base pressure or temperature used. Moreover, with the selected sodium reactor outlet temperature of $1000^{\circ} \mathrm{F}$, the average range to be examined in Task III, $900^{\circ} \mathrm{F}$ steam is reasonable. This temperature provides a good heat rate and yet allows sufficient heat exchanger $\Delta \mathrm{T}$ for the steam generator surface area. The selected throttle pressure of 2400 psig meets modern advanced steam conditions, leading to use of standard turbine plant equipment. 
SECTION 4

TURBINE PLANT CYCLE AND EQUIPMENT

\subsection{Turbine Plant Cycle}

The turbine plant functional specifications for steam reheat or moisture separation, and for sodium reheat are presented in Table 3. A constant heat input of 2600 MWt was selected to provide a nominal net power output of 1000 MWe. Condenser back-pressure of 1.5 inches of mercury absolute and 0 percent make-up were assumed to conform to the rating requirements of TID-7025. [3]

TABLE 3

TURBINE PLANT FUNCTIONAL SPECIFICATIONS

\begin{tabular}{|l|c|c|}
\hline & $\begin{array}{c}\text { Steam Reheat or } \\
\text { Moisture Separation }\end{array}$ & $\begin{array}{c}\text { Sodium Reheat } \\
\text { Cycle }\end{array}$ \\
\hline Throttle Steam Pressure (psig) & 2400 & 2400 \\
Throttle Steam Temperature $\left({ }^{\circ} \mathrm{F}\right)$ & 900 & 900 \\
Reheat Steam Temperature ( $\left.{ }^{\circ} \mathrm{F}\right)$ & To be determined & 900 \\
Feedwater Temperature ( $\left.{ }^{\circ} \mathrm{F}\right)$ & 500 & 500 \\
Heat Input (MWt) & 2600 & 2600 \\
Condenser Back Pressure (in Hg A) & 1.5 & 1.5 \\
Make-Up (\%) & 0 & 0 \\
No. Separate Turbine-Driven BFP & 2 & Yes \\
Condenser Suitable for 40\% Full-load & Yes & \\
Steam Dump at Full Pressure for 4 min. & & \\
\hline
\end{tabular}


A preliminary evaluation of numerous different combinations of low-pressure end size, configuration, moisture separation, and steam reheat at several bleed points was made, comparing rough incremental heat rates and equipment price differences. For the throttle steam conditions used, moisture separation was selected over steam reheat.

Based upon the above work, a heat balance was prepared for the moisture separation cycle utilizing an $1800 \mathrm{rpm}$ tandan compound unit with quadruple flow, 44inch, low-pressure blades. The detailed heat balance is presented in Figure 2. This shows a turbine cycle heat rate of $8264 \mathrm{Btu} / \mathrm{kWh}$ with a generator output of 1073.8 MWe and separate turbine-driven feedwater pump power of 32.13 MW or gross power output of 1106 MWe. Seven stages of regenerative feedwater heating were selected and the feedwater returns at $500^{\circ} \mathrm{F}$ to the steam generator.

The separate, turbine-driven, twin 50-percent capacity, high-pressure feedwater pumps require $32.13 \mathrm{MW}$. A description of the turbine-generator unit follows: One 1,073,843 kW indoor-type, turbine-generator unit for use with a sodiumcooled, fast breeder nuclear reactor consisting of:

One Tandem compound, four-flow, three-casing, impulse-reaction, indoortype, condensing 1,800-rpm turbine, utilizing 44-inch last row blades guaranteed to deliver $1,073,843 \mathrm{~kW}$ net (measured at the generator terminals) when operating with rated steam conditions of 2,415 psia, 900 degrees FTT (Final Throttle Temperature) at the turbine stop valves, one stage of external moisture separation between the HP (High-Pressure) and LP (Low-Pressure) elements, 1.5-inch-Hg abs exhaust, all seven stages of feedwater heating in service, zero percent makeup, and while extracting steam for condensing-type boiler feed pump turbine(s). This corresponds to the NSSS (Nuclear Steam Supply System) output of 2,600 MWt; To provide for manufacturing tolerances, the main turbine will be designed with five percent flow margin above the flow required to meet the guaranteed output. Thus, the turbine-generator unit has a maximum calculated (not guaranteed) net output (measured at the generator terminals) of $1,117,028 \mathrm{~kW}$, when operating with the governing valves wide open at steam conditions of 2,415 psia, 900-degree FTT at the turbine 


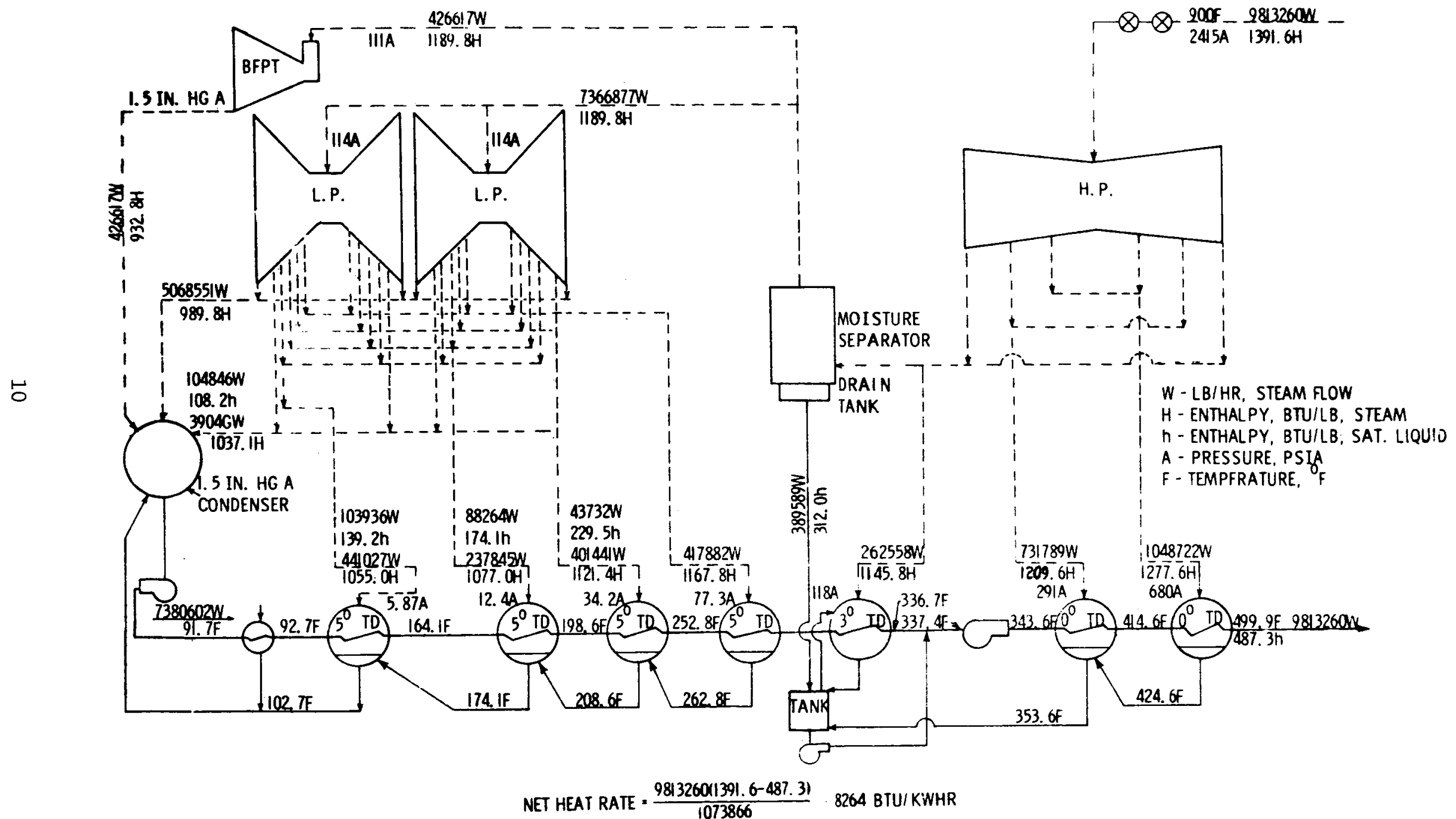

Figure 2. Moisture Separation Cycle, Turbine Plant, Detailed Heat Balance 
stop valves, external moisture separator in service, 1.5 -inch-Hg abs exhaust, all seven stages of feedwater heating in service, zero percent makeup, and while extracting steam for condensing type boiler feed pump turbines.

One 1,241,100 kVa, $0.90 \mathrm{p}-\mathrm{f}, 0.58 \mathrm{SCR}$, at maximum hydrogen pressure, 3-phase, 60 cycle, 22,000-volt, 1,800-rpm, hydrogen inner-cooled generator.

One 600-volt dc, 1,800-rpm, self-ventilated, air-cooled, shaft-driven brushless exciter complete with static-type voltage regulator and associated excitation switchgear.

The quoted price includes moisture separators, standard features and accessories, f.o.b. point of shipment with freight prepaid to rail siding nearest the installation site, and installation services of a qualified engineer. The size and weight of major components of the turbine-generator unit and external moisture separator are presented in Figures 3, 4, and 5.

To make a valid comparison, the sodium reheat plant incorporated the same lowpressure ends that were used for the moisture separation turbine. The detailed heat balance for this sodium reheat cycle is shown in'Figure 6 . As before, there are seven stages of regenerative feedwater heating resulting in a net turbine plant heat rate of $8063 \mathrm{Btu} / \mathrm{kWh}$. The heat rate gain is approximately $200 \mathrm{Btu} / \mathrm{kWh}$. The turbine-generator unit description follows:

One 1,100,777 kW indoor-type turbine-generator unit consisting of:

One cross-compound, four-flow, four-casing, impulse-reaction, indoortype condensing, 3600/1800-rpm turbine, utilizing 44-inch, last-row blades guaranteed to deliver $1,100,777 \mathrm{~kW}$ net (measured at the generator terminals) when operating with rated steam conditions of 2415 psia, 900-degree FTT at the turbine stop valves, reheating to 900 degrees FTT, 1.5-inch-Hg abs exhaust, all seven stages of feedwater heating in service, zero percent makeup, and while extracting steam for condensingtype boiler feed pump turbines. This corresponds to the NSSS output of $2600 \mathrm{MWt}$; 


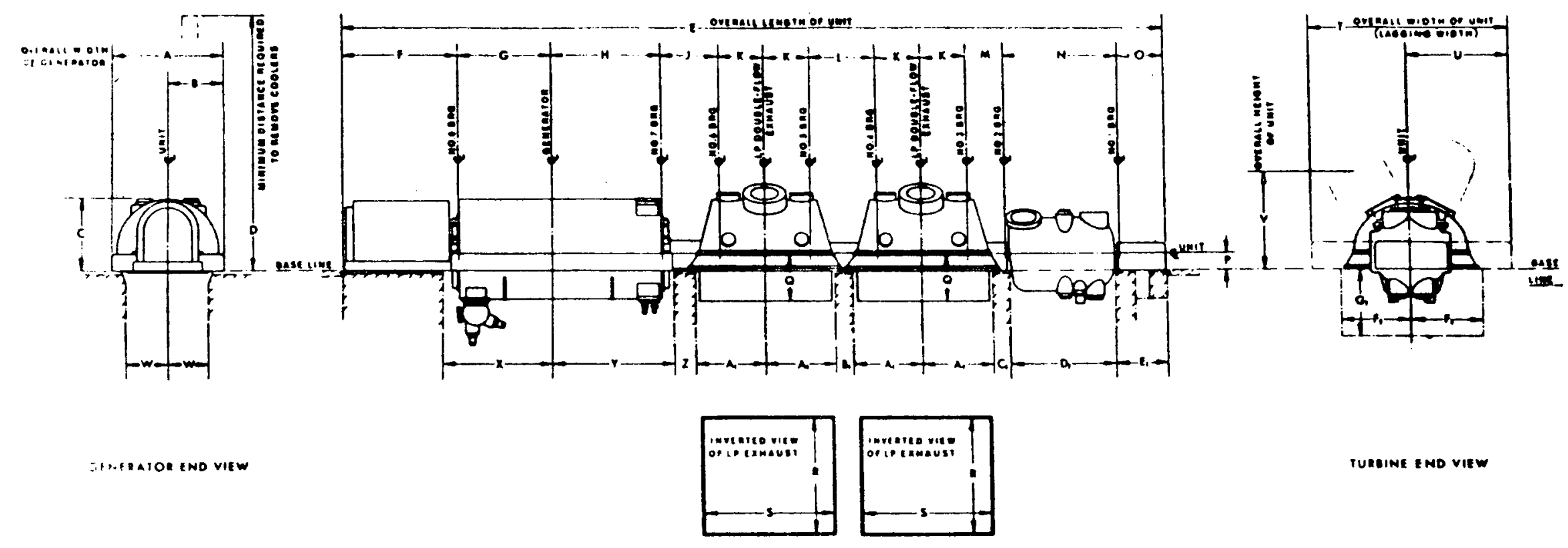

$\overline{\mathrm{N}}$

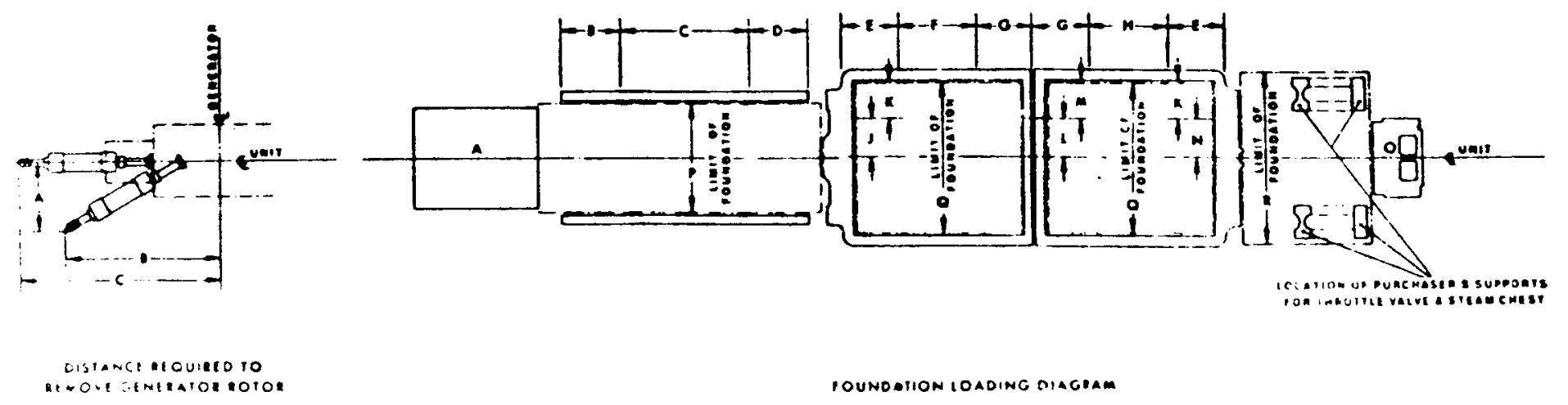

NOTE: FOR MOISTURE SEPARATOR DATA, SEE ATTACHED SHEET.

Figure 3. Moisture Separation Turbine 
WESTINOMOUSE TURUME. ORNERATOR UNIT PROPOSAL OUTINE

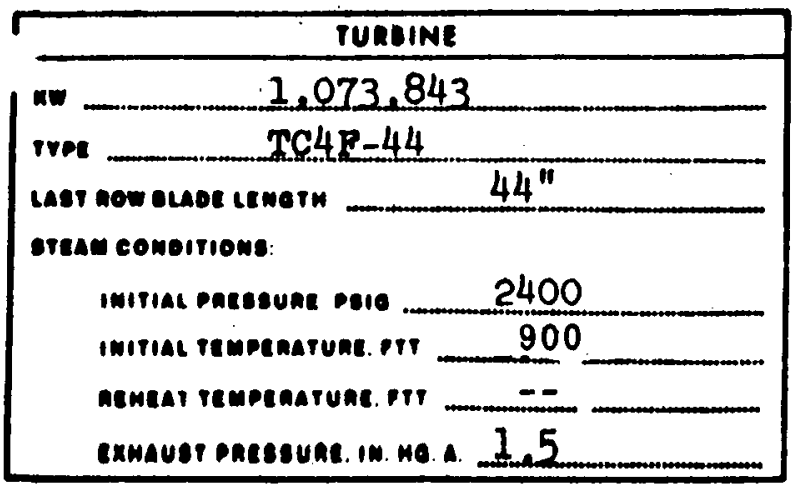

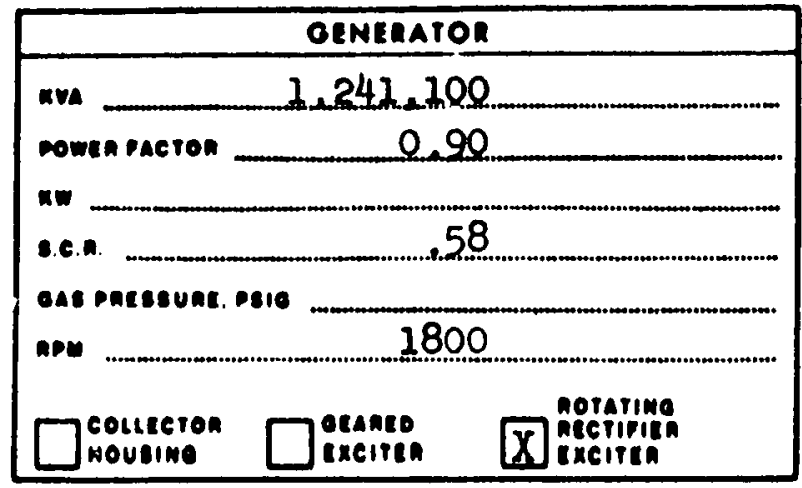

\begin{tabular}{|c|c|c|c|}
\hline \multicolumn{4}{|c|}{ OUTIINE DIMENSIONS } \\
\hline 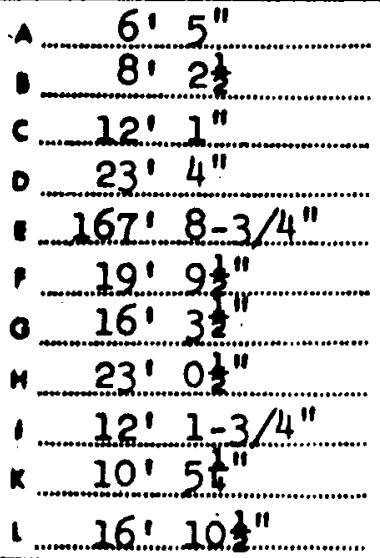 & 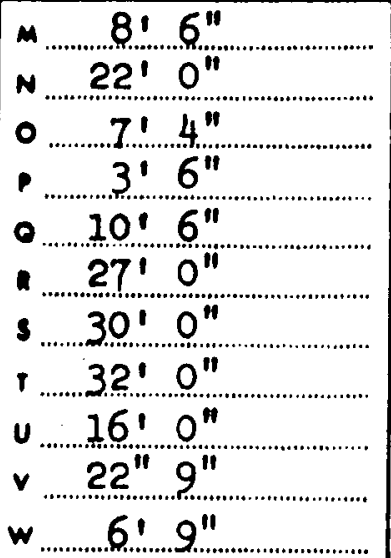 & 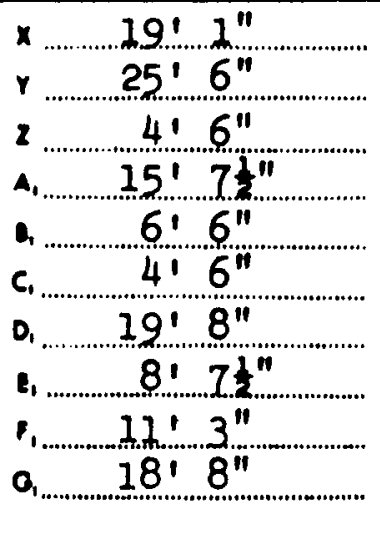 & 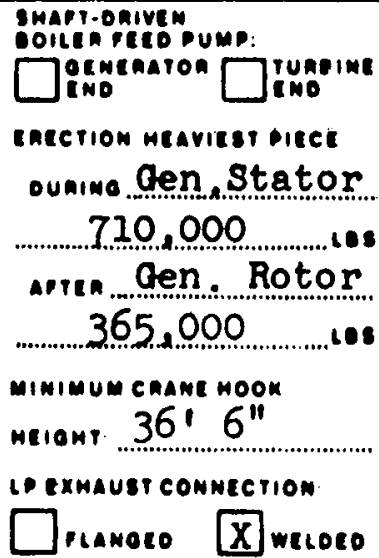 \\
\hline
\end{tabular}

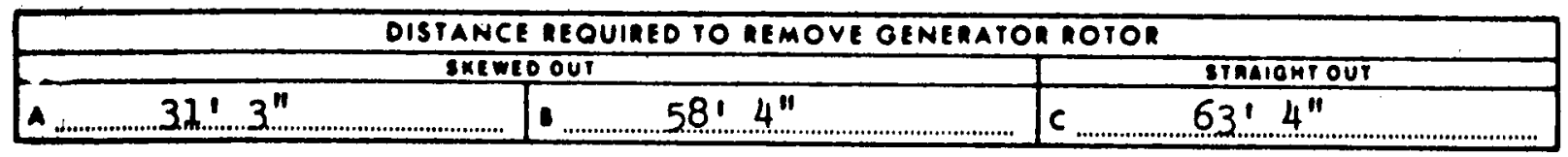

\begin{tabular}{|c|c|c|}
\hline \multicolumn{3}{|c|}{ POUNDATION LOADINO DIAGRAM } \\
\hline 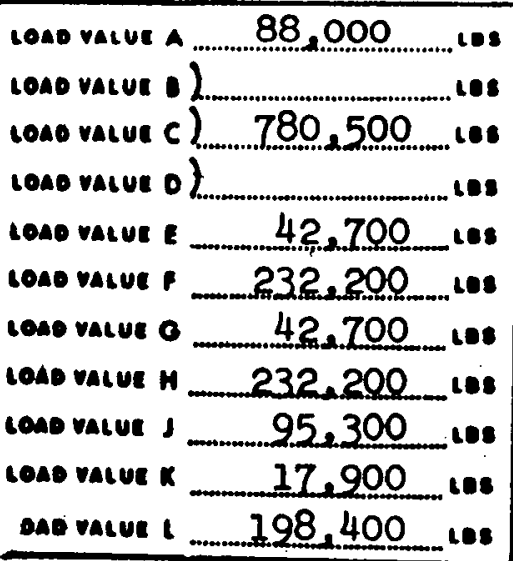 & 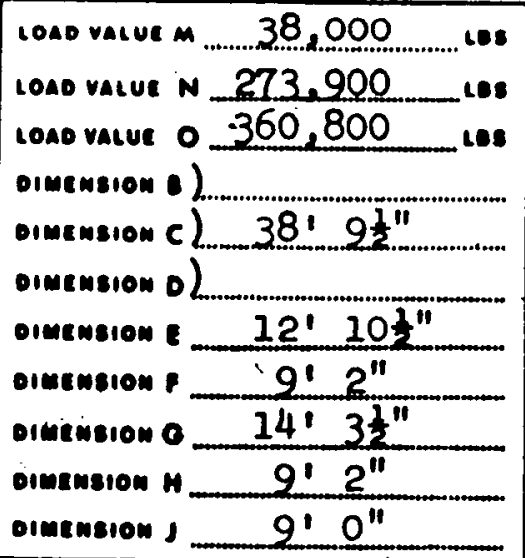 & 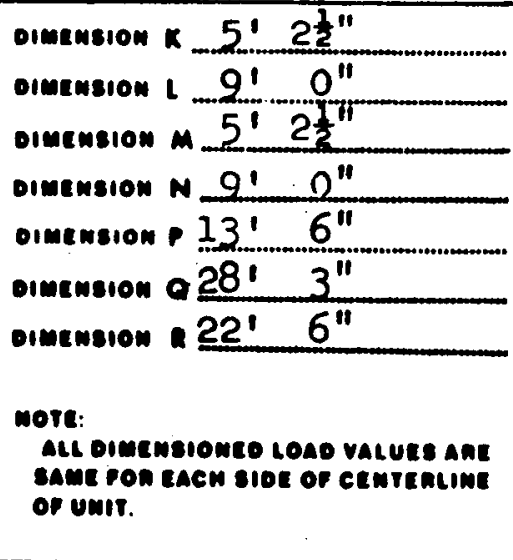 \\
\hline
\end{tabular}

All dimensions are approximate.

macmase" ARD 1000 MW LMFBR Study contract

Figure 4 Dimensions, Moisture Separation Turbine 


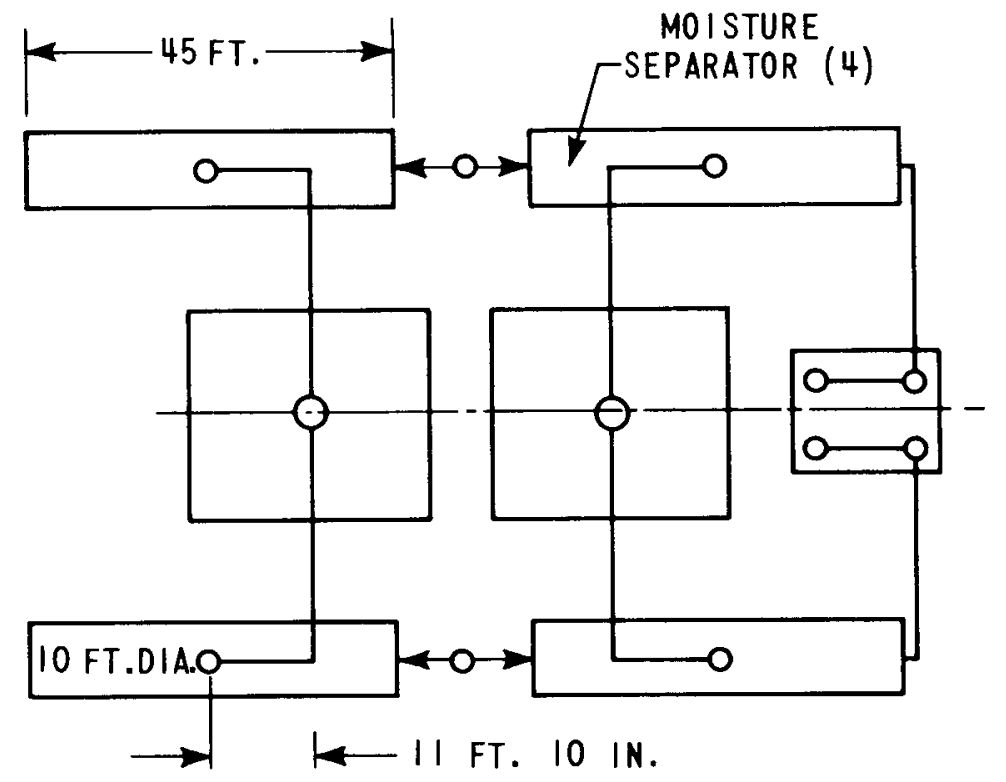

MOISTURE SEPARATOR TANKS MAY BE

LOCATED EITHER ABOVE OR BELOW FLOOR.

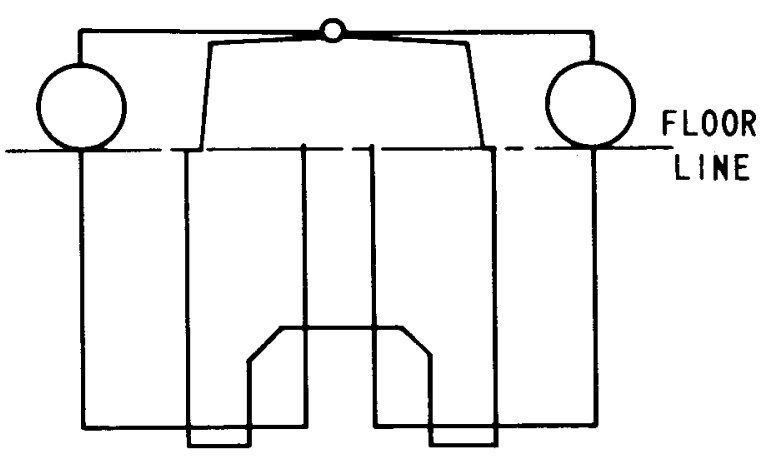

OPERATING WE IGHT OF EACH MOISTURE SEPARATOR TANK 70.000 LBS 


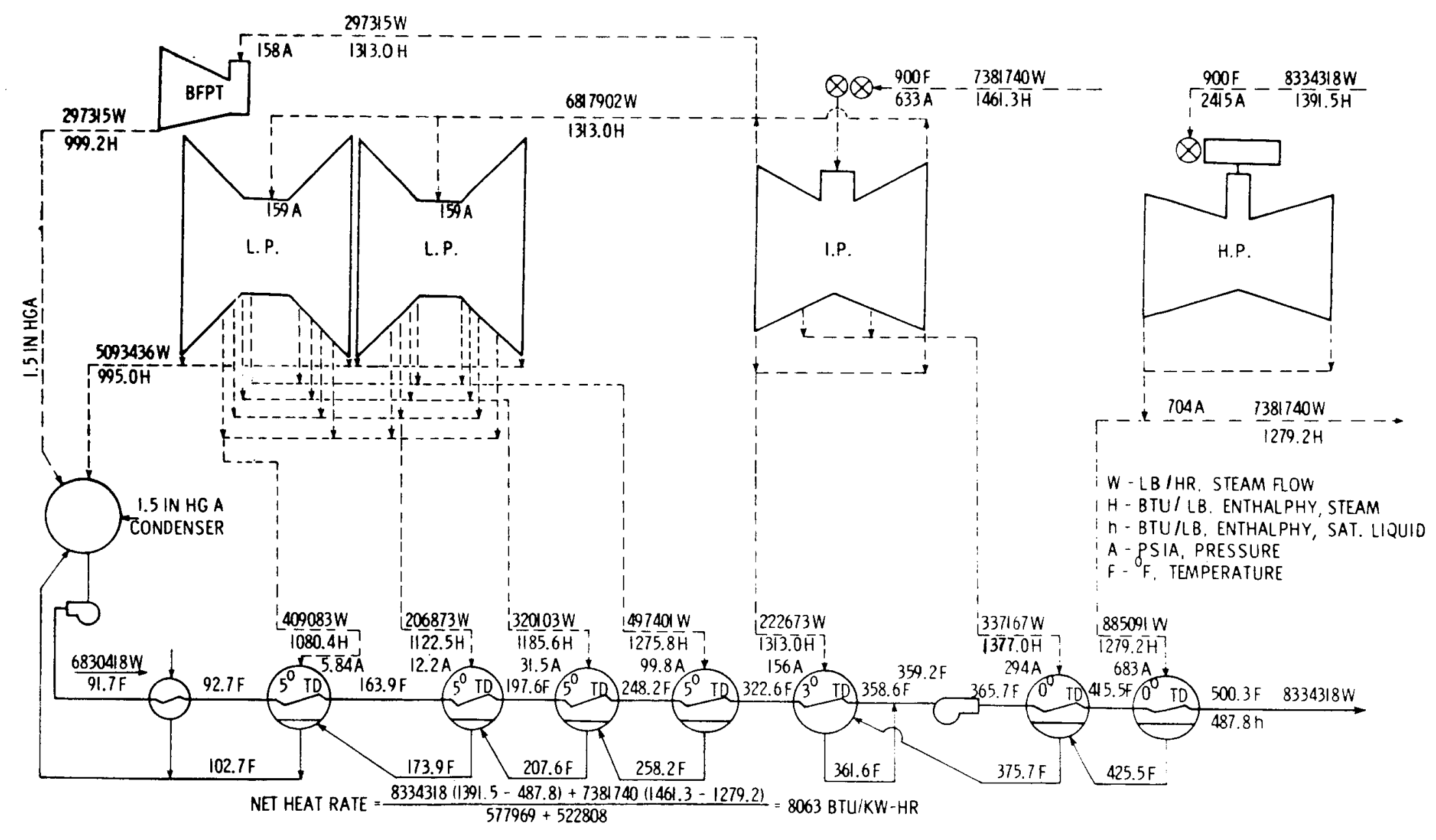

Figure 6. Heat Balance Schematic, Sodium Reheat 
To provide for manufacturing tolerances, the main turbine will be designed with five percent flow margin above the flow required to meet the guaranteed output. Thus, the turbine-generator unit has a maximum calculated (not guaranteed) net output (measured at the generator terminals) of $1,143,665 \mathrm{~kW}$, when operating with the governing valves wide open at steam conditions of 2415 psia, 900-degree FTT at the turbine stop valves, reheating to 900 degrees FTT, 1.5-inch-Hg absolute exhaust, all seven stages of feedwater heating in service, zero percent makeup, and while extracting steam for condensing-type boiler feed pump turbines.

One $664,300 \mathrm{kVa}, 0.90 \mathrm{p}-\mathrm{f}, 0.58 \mathrm{SCR}$, at maximum hydrogen pressure, 3-phase, 60-cycle, 20,000 volt, 3600-rpm, hydrogen inner-cooled generator.

One $606,500 \mathrm{kVa}, 0.90 \mathrm{p}-\mathrm{f}, 0.58 \mathrm{SCR}$, at maximum hydrogen pressure, 3-phase, 60-cycle, 20,000 volt, 1800-rpm, hydrogen inner-cooler generator.

One 500-volt dc, 3600-rpm, self-ventilated, air-cooled, shaft-driven brushless exciter.

One 500-volt dc, 1800-rpm, self-ventilated, air-cooled, shaft-driven brushless exciter.

One static-type voltage regulator and associated excitation switchgear.

The quoted price includes standard features and accessories, f.o.b. point of shipment with freight prepaid to rail siding nearest the installation site, and installation services of a qualified engineer. Figures 7 through 10 show the size and weight of major components of the turbine-generator unit.

Figure 11 shows a comparison of the steam cycle expansion lines for the moisture separation cycle and sodium reheat cycle.

Figure 12 gives a comparison of the relative turbine performance for different nominal 1000 MWe plant studies. It is seen that for a sodium reheat cycle with 2400 psig and 900 or $950^{\circ} \mathrm{F}$ steam, Atomics International (AI), U-E, and WARD 


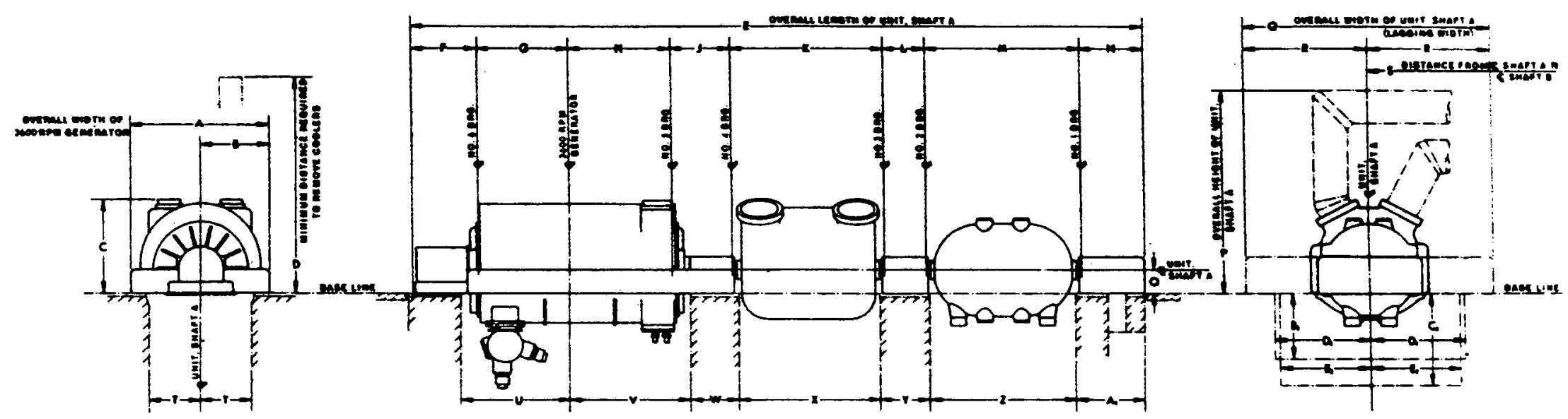

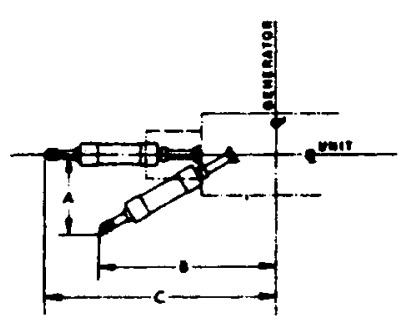

DisTance REOUIEE TO
move genteatoa Roto

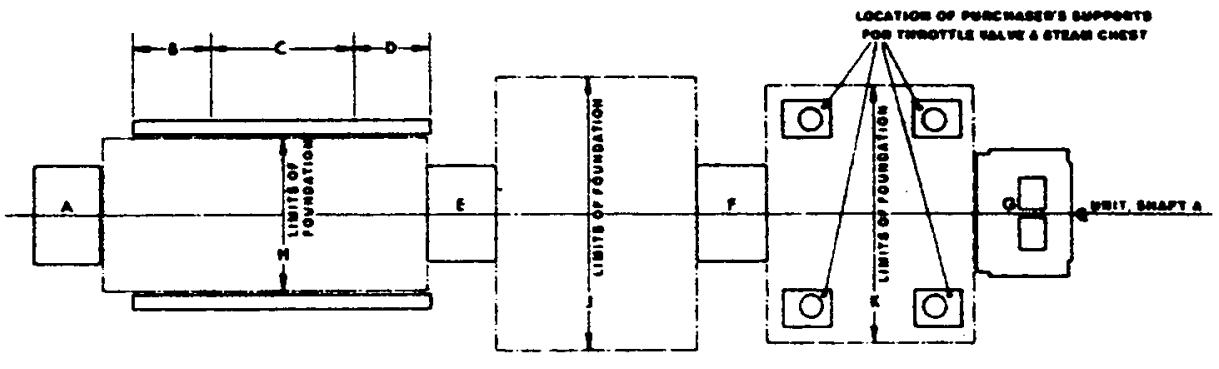

ROUNDATION LOAOIMG DRACRN 
WESTINGHOUSE TURBINE.GENERATOR UNIT PROPOSAL OUTLINE

IR 1038

SHAFT A

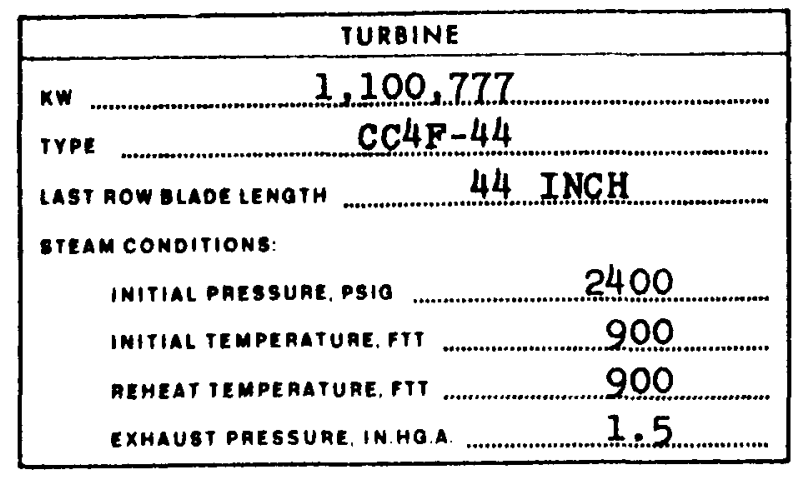

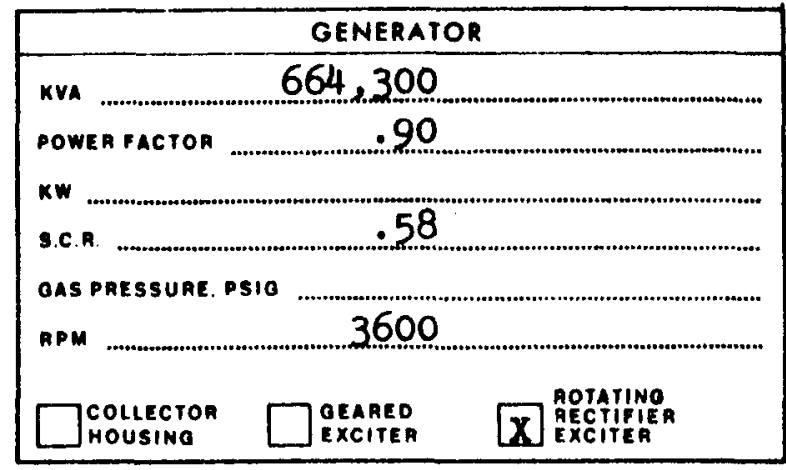

\begin{tabular}{|c|c|c|c|}
\hline \multicolumn{4}{|c|}{ OUTLINE DIMENSIONS } \\
\hline $14^{\prime} 6^{\prime \prime}$ & $15^{1} 0^{11}$ & v $21^{\prime} 7-1 / 2^{\prime \prime}$ & $\begin{array}{l}\text { SHAFT-ORIVEN } \\
\text { BOILER PEED PUMP: }\end{array}$ \\
\hline $87^{1} 3^{\prime \prime}$ & M $18^{1} 6^{\prime \prime}$ & 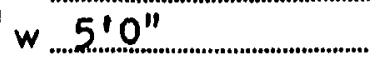 & $\square$ EENDEATOR $\square$ TUAGOINE \\
\hline c $10^{\prime} 5^{\prime \prime}$ & N $7^{1} 9^{\prime \prime}$ & $\times 16^{\prime} 7-1 / 2^{\prime \prime}$ & EAECTION HEAVIEST PIECE: \\
\hline D $25^{\prime 2} 4^{\prime \prime}$ & 0.2!6" & 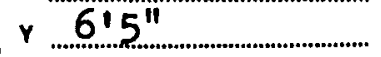 & ourina Gen.stator \\
\hline E $10813^{\prime \prime}$ & P $23^{\prime} 0^{\prime \prime}$ & 2 & 685.100 \\
\hline $18^{\prime} 2^{\prime \prime}$ & Q ....30!9"1 & A.. $.110^{11}$ & arten Gen.gotor \\
\hline - $14 ! 10-1 / 2^{\prime \prime}$ & R $15: 4-1 / 2 "$ & 8....13! 8, & 120,200 \\
\hline${ }^{H} \frac{19 ! 6-1 / 2^{\prime \prime}}{6 ! 5^{\prime \prime}}$ & s $\frac{34 ! 6^{\prime \prime}}{5 ! 8^{\prime \prime}}$ & 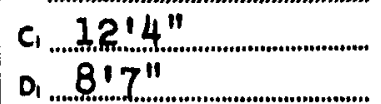 & $\begin{array}{l}\text { MINIMUM CAANE HOOK } \\
\text { MEIOHT: ...... } 36 ! 6 \text { "...... }\end{array}$ \\
\hline${ }^{181} 0^{\prime \prime}$ & U $17^{\prime} 1^{\prime \prime}$ & $E_{1} . . .9 ! 0^{\prime \prime}$ & LP EXHAUST CONNECTION: \\
\hline & & & Dilanged \\
\hline
\end{tabular}

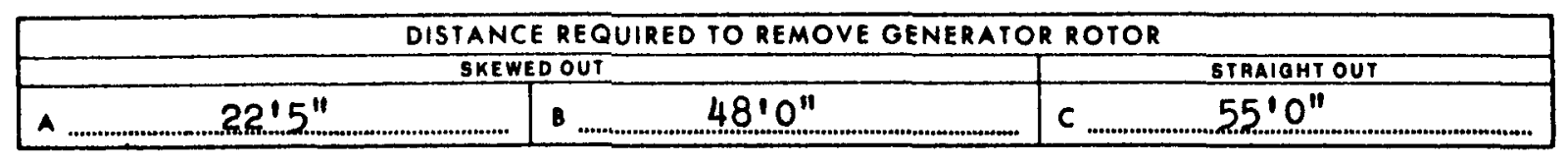

\begin{tabular}{|c|c|c|}
\hline \multicolumn{3}{|c|}{ FOUNDATION LOADING DIAGRAM } \\
\hline 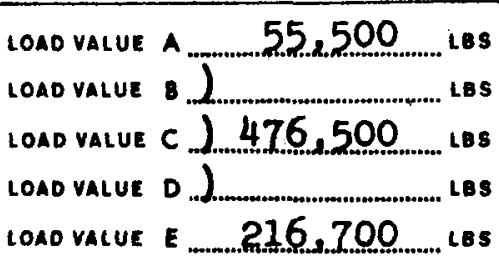 & 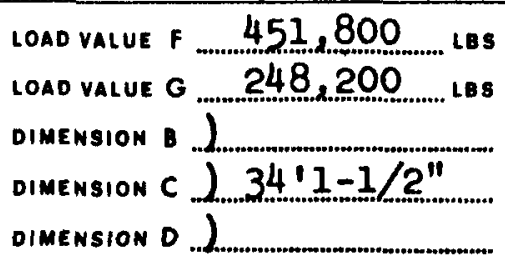 & 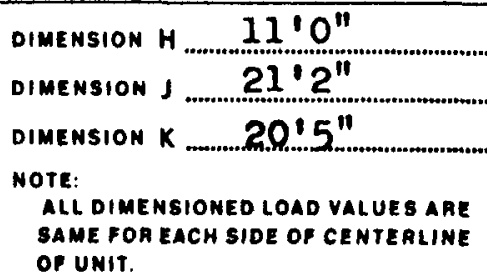 \\
\hline
\end{tabular}

\section{A11 Dimensions Are Approximate}

PURCHASER ARD 1000 MW LMPBR study Contract

Figure 8 Dimensions, Sodium Reheat Turbine, Shaft A 


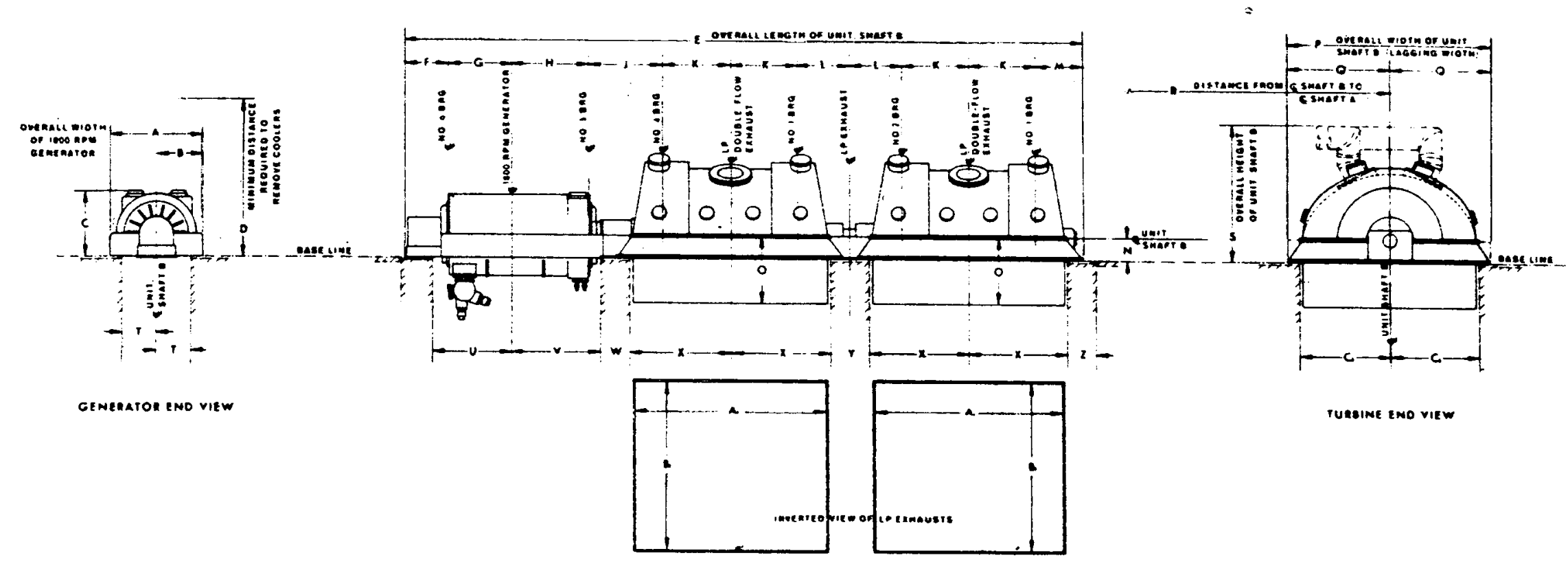

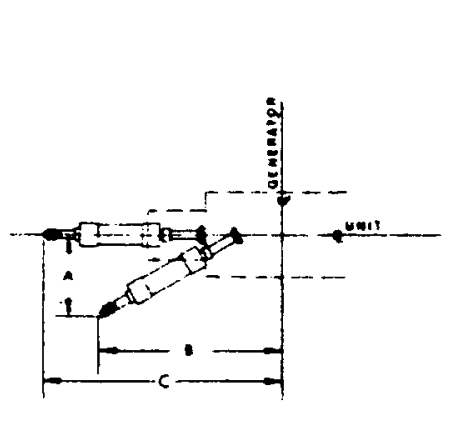

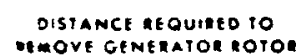

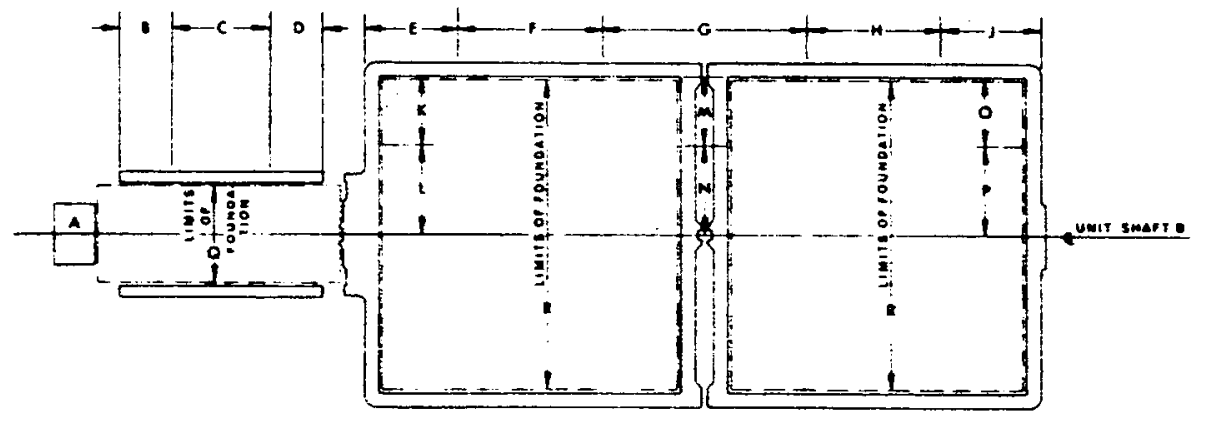

MOUNDATION IOAOING DIAGRAM 
WESIINGGOUSE IURBINE.GENERATOR UNIT PROPOSAL OUTLINE

SHAFT B

TR 1040

\begin{tabular}{|c|c|}
\hline TURBINE & GENERATOR \\
\hline 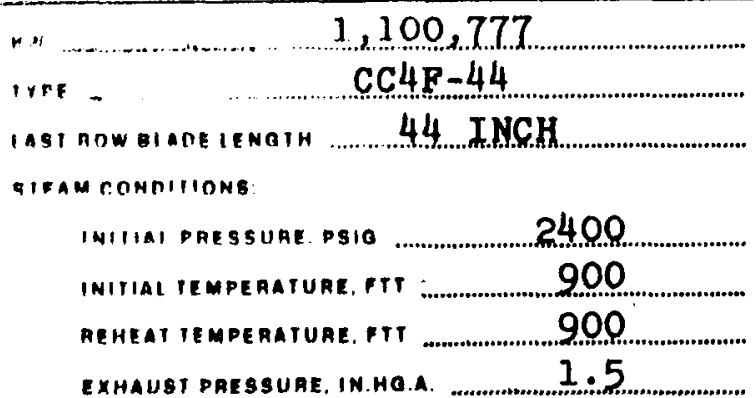 & 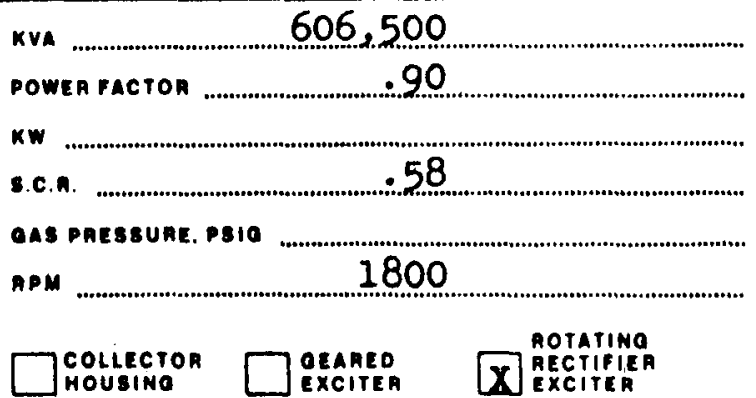 \\
\hline
\end{tabular}

\begin{tabular}{|c|c|c|c|}
\hline \multicolumn{4}{|c|}{ OUTLINE DIMENSIONS } \\
\hline A $13^{\prime} 9^{\prime \prime}$ & $8: 5-1 / 4 "$ & $v \quad 21^{17}-1 / 2^{11}$ & $\begin{array}{l}\text { 8HAFT-DAIVEN } \\
\text { BOILEA FEED PUMP: }\end{array}$ \\
\hline $6^{\prime} 10-1 / 2^{\prime \prime}$ & $9: 7-1 / 2^{\prime \prime}$ & w $4 \cdot 6^{\prime \prime}$ & $\square{ }_{\text {END }}^{\text {OENEAATOA }} \square \square_{\text {END }}^{\text {TUREINE }}$ \\
\hline c $9110^{11}$ & $3^{\prime} 6^{\prime \prime}$ & $\times \quad 15^{\prime} 7-1 / 2^{11}$ & EAECTION HEAVIEST PIECE: \\
\hline D 21.811 & - $10^{\prime} 6^{\prime \prime}$ & y $6 \cdot 6 !$ & ounina Gen Stator. \\
\hline E $133: 8-3 / 4$ " & P $32^{\prime} 0^{\prime \prime}$ & $266^{\prime \prime}$ & 640,000 \\
\hline $20^{\prime} 2^{11}$ & a $16^{\prime} 0^{\prime \prime}$ & $30^{\prime} 0^{\prime \prime}$ & arter Gen Rotor \\
\hline - $1410 " 1$ & $=316 "$ & a. $27^{\prime} 0^{11}$ & 235,000 \\
\hline " $19^{\prime} 7^{\prime \prime}$ & s $23^{\prime} 0^{\prime \prime}$ & c $\ldots 14 ! 1-1 / 2^{\prime \prime}$ & MINIMUM CAANE HOOK \\
\hline, $11 \cdot 8-3 / 4 "$ & $5^{1} 2^{11}$ & & 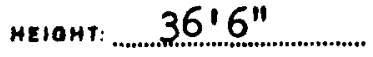 \\
\hline k $10^{\prime} 5-1 / 4^{\prime \prime}$ & u $16^{\prime} 4-1 / 2^{\prime \prime}$ & & LP EXHAUST CONNECTION: \\
\hline & & & Dilanged $X$ weloedo \\
\hline
\end{tabular}

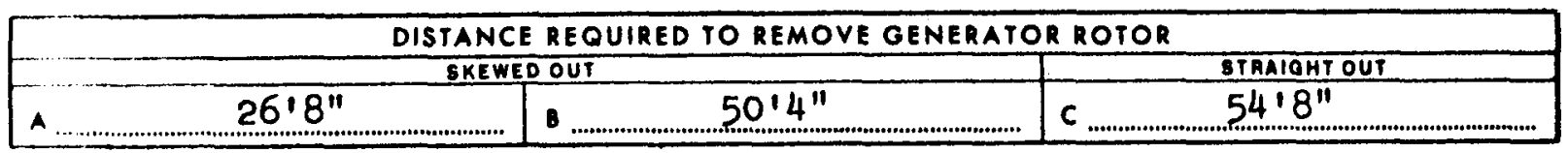

\begin{tabular}{|c|c|c|}
\hline \multicolumn{3}{|c|}{ FOUNDATION IOADING DIAGRAM } \\
\hline 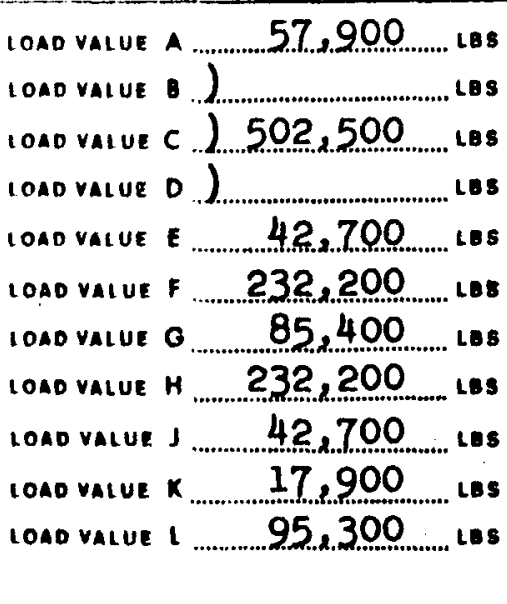 & 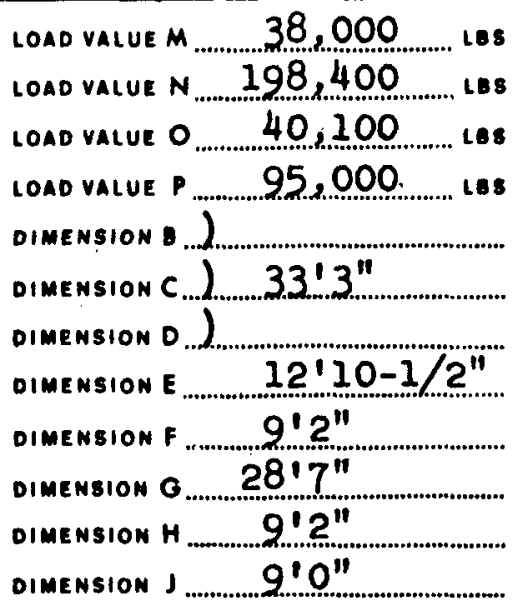 & 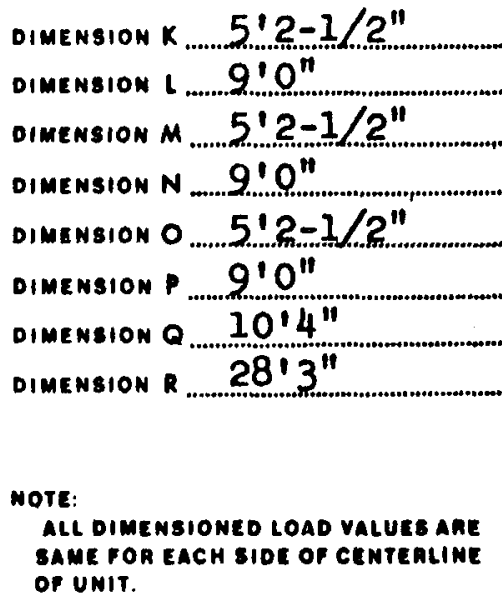 \\
\hline
\end{tabular}

A11 Dimensions Are Approximate

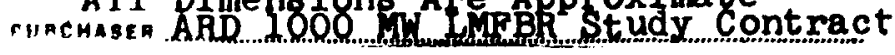

Figure 10 Dimensions. Sodium Reheat Turbine, Shaft b 


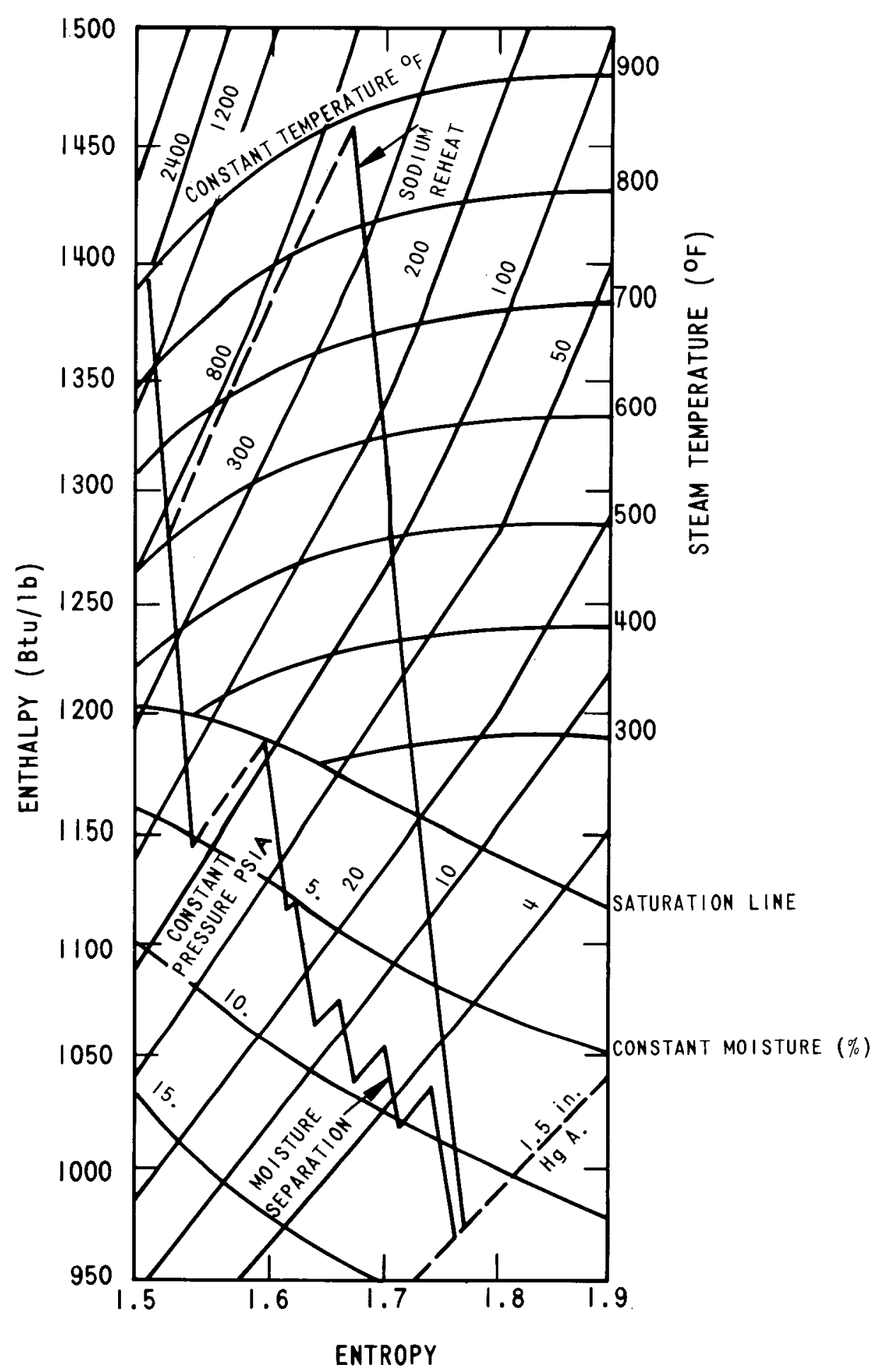

Figure 11 Mollier Diagram, Moisture Separation and Sodium Reheat 3095-2 


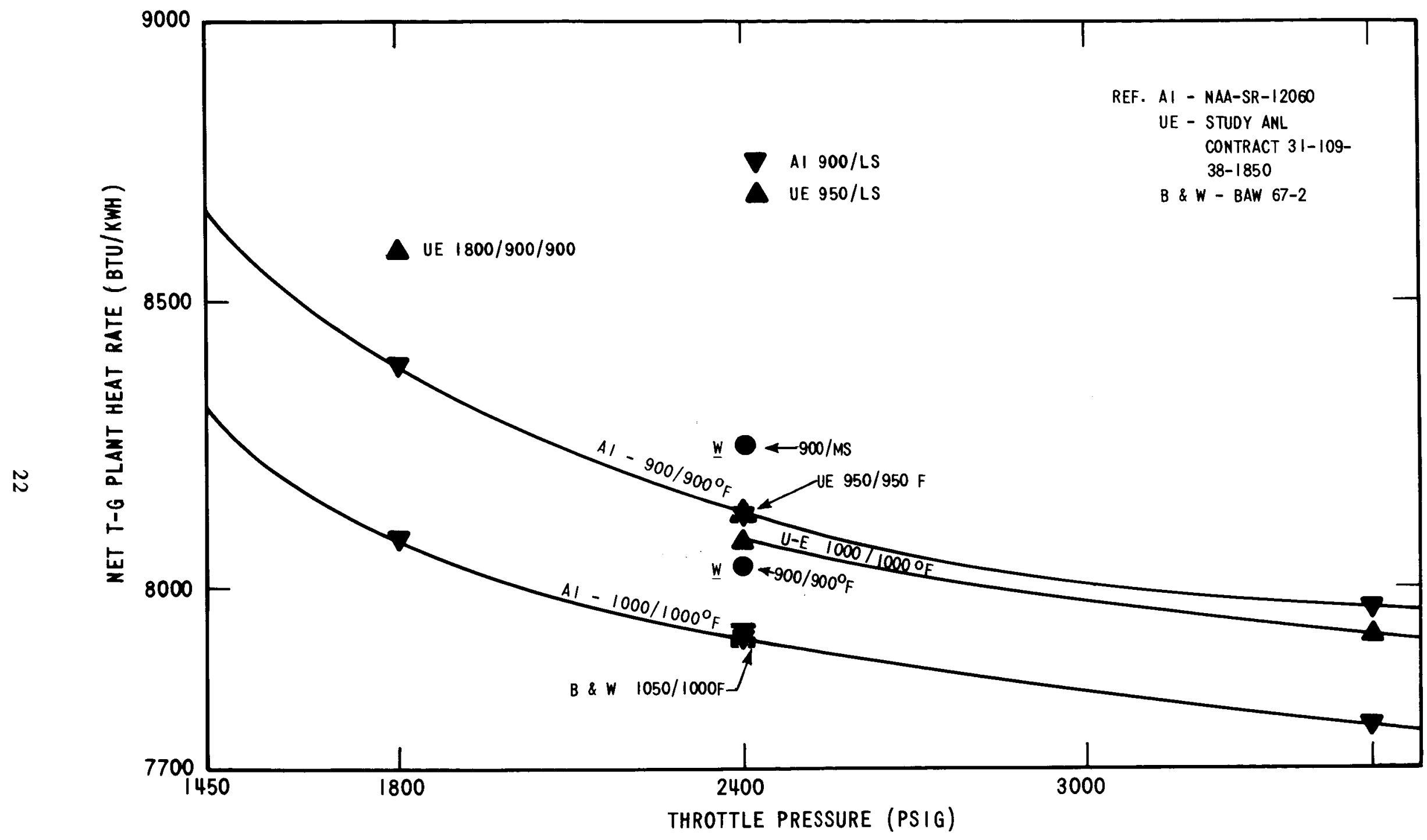

Figure 12. Comparison of Turbine Plant Net Heat Rates for Various Throttle Steam Conditions 
all arrived at heat rates which are within 100 to $150 \mathrm{Btu} / \mathrm{kWh}$. The Westinghouse heat rate is the lowest, and is based on the most detailed of the three studies. For the moisture separation, or steam reheat cases, AI and U-E agree rather closely on heat rate, whereas the Westinghouse value is about $400 \mathrm{Btu} / \mathrm{kWh}$ lower. The Westinghouse moisture separation cycle uses the improvements developed for the Westinghouse prototype study. Preliminary considerations indicated that steam reheat does not give sufficient gain in heat rate to compensate for the additional reheater capital cost.

Table 4 compares the two plant cycles. The net plant heat rate is 8490 for moisture separation and $8281 \mathrm{Btu} / \mathrm{kWh}$ for the reheat plant.

\subsection{Condenser Design}

The condenser designs for the two steam cycles are based upon the heat balances shown in Figures 2 and 6 . The following assumptions were used to size the equipment:

a. Condenser cooling is supplied by river water at $57^{\circ} \mathrm{F}$ (to agree with AEC-selected Middletown Site).

b. Elevation of the site with respect to minimum river level is such that an all-friction, circulating water system may be used.

c. Circulating water friction external to the condenser is 15 feet of water.

d. There will be a limit of $15^{\circ} \mathrm{F}$ placed on the circulating water temperature rise.

e. The maximum width of the condenser shell will be four feet greater than the width of the turbine exhaust.

f. A basement floor-to-turbine floor height of 40 feet is available with a 10-foot-deep turbine beam, with allowance for a five-foot diameter LP heater stage in the neck.

g. The tubes are made of Type 304 stainless steel.

h. The tubesheets are made of carbon steel. 
TABLE 4

COMPARISON OF MOISTURE SEPARATION AND REHEAT CYCLES

\begin{tabular}{|c|c|c|}
\hline & $\begin{array}{c}\text { Moisture } \\
\text { Separation }\end{array}$ & $\begin{array}{l}\text { Sodium } \\
\text { Reheat }\end{array}$ \\
\hline \multicolumn{3}{|l|}{ High-Pressure } \\
\hline Number of double flow cylinders & 1 & 1 \\
\hline Inlet pressure (psig) & 2400 & 2400 \\
\hline Inlet temperature $\left({ }^{\circ} \mathrm{F}\right)$ & 900 & 900 \\
\hline Inlet enthalpy (Btu/1b) & 1391.6 & 1391.6 \\
\hline Flow $\left(10^{6} 1 \mathrm{~b} / \mathrm{hr}\right)$ & 9.813 & 8.33 \\
\hline Discharge pressure (psia) & 122 & 704 \\
\hline Discharge temperature $\left({ }^{\circ} \mathrm{F}\right)$ & 342.5 & 512 \\
\hline Discharge enthalpy (Btu/Ib) & 1145.6 & 1209.2 \\
\hline Discharge moisture (\%) & 5.1 & $\mathrm{SH}$ \\
\hline \multicolumn{3}{|l|}{ Intermediate Pressure } \\
\hline Number of double flow cylinders & Integral with HP & 1 \\
\hline Inlet pressure (psia) & -- & 633 \\
\hline Inlet temperature $\left({ }^{\circ} \mathrm{F}\right)$ & -- & 900 \\
\hline Inlet enthalpy (Btu/1b) & -- & 1461.3 \\
\hline Flow $\left(10^{6} \mathrm{lb} / \mathrm{hr}\right)$ & -- & 7.382 \\
\hline Discharge pressure (psia) & -- & 163 \\
\hline Discharge temperature $\left({ }^{\circ} \mathrm{F}\right)$ & -- & 577 \\
\hline Discharge enthalpy (Btu/lb) & -- & 1313 \\
\hline
\end{tabular}


TABLE 4 (Cont)

COMPARISON OF MOISTURE SEPARATION AND REHEAT CYCLES

\begin{tabular}{|l|c|c|}
\hline & $\begin{array}{c}\text { Moisture } \\
\text { Separation }\end{array}$ & $\begin{array}{c}\text { Sodium } \\
\text { Reheat }\end{array}$ \\
\hline Low-Pressure & 2 & 2 \\
Number of double flow cylinders & 114 & 159 \\
Inlet pressure (psia) & 337 & 577 \\
Inlet temperature ( ${ }^{\circ} \mathrm{F}$ ) & 1189.8 & 1313 \\
Inlet enthalpy (Btu/1b) & 7.367 & 6.251 \\
Flow (106 1b/hr) & 1.5 \\
Discharge pressure (in Hg A) & 500 & 500 \\
Feedwater temperature ( ${ }^{\circ}$ F) & & 2600 \\
\hline Power Conversion & 2600 & 1128.1 \\
Heat input (MWt) & 1106.0 & 29.4 \\
Gross power output (MWe) & 33.8 & 27.0 \\
Turbine plant auxiliary power (MWe) & 27.0 & 1071.7 \\
Reactor plant auxiliary power (MWt) & 1045.2 & 8281 \\
Net plant output (MWe) & 8490 & 41.22 \\
Net plant heat rate (Btu/kWh) & 40.20 & \\
Net plant efficiency (\%) & & \\
\hline
\end{tabular}


i. The waterboxes and shell are made of A-285 Grade C steel.

j. The expansion joint is made of rubber belting.

k. A five-minute condensate storage will be provided in the hotwell.

1. Tubes are one-inch-diameter 22 BWG.

m. A cleanliness factor of 90 percent is used.

n. The condenser pressure is fixed at 1.5-inch-Hg abs by the customer.

In both the base plant moisture separation cycle and the reheat plant alternate, two condensers are required, mounted perpendicular to the turbine shaft. The basic design information is presented in Table 5 and outlines are given in Figures 13 and 14. The associated condenser equipment is described in the following pages. Prices for the condensers and associated condenser equipment were estimated.

TABLE 5

CONDENSER PARAMETERS

\begin{tabular}{|l|c|c|}
\hline & Base Plant & Reheat Plant \\
\hline Number of condensers & 2 & 2 \\
Surface area of each (ft $\left.{ }^{2}\right)$ & 217,000 & 213,500 \\
Circulating water required (gpm) & 346,500 & 341,000 \\
Velocity in tubes (ft/sec) & 7.25 & 7.25 \\
Tubes diam/gage (in/BWG) & $1 / 22$ & $1 / 22$ \\
Tube material & $304 \mathrm{SS}$ & $304 \mathrm{SS}$ \\
Cleanliness factor (\%) & 90 & 90 \\
Number of passes & 1 & 1 \\
Inlet water temperature ( $\left.{ }^{\circ} \mathrm{F}\right)$ & 57 & 57 \\
Circulating water rise $\left({ }^{\circ} \mathrm{F}\right)$ & 14.85 & 14.85 \\
\hline
\end{tabular}




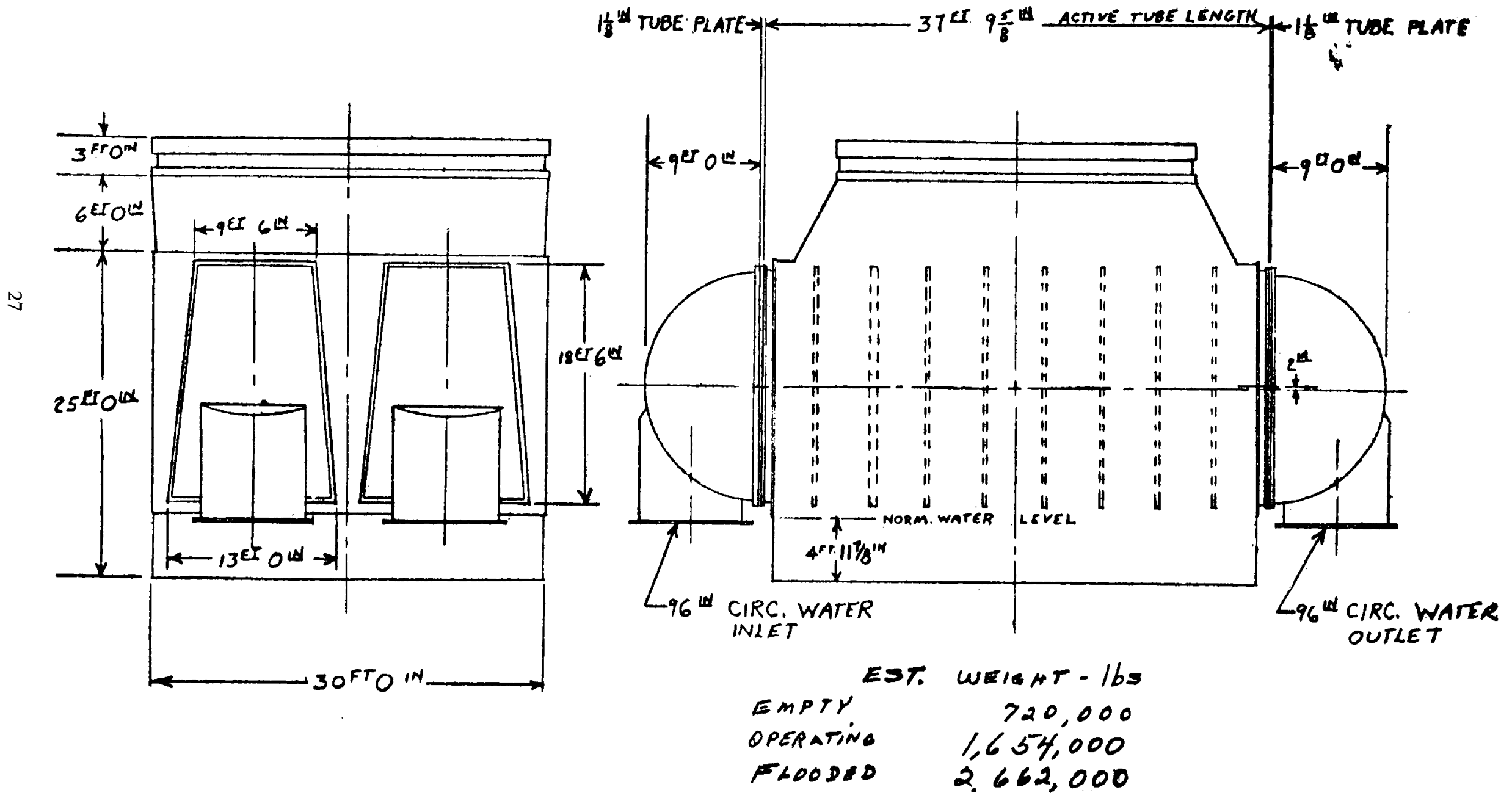

Figure 13. Base Plant Condenser 


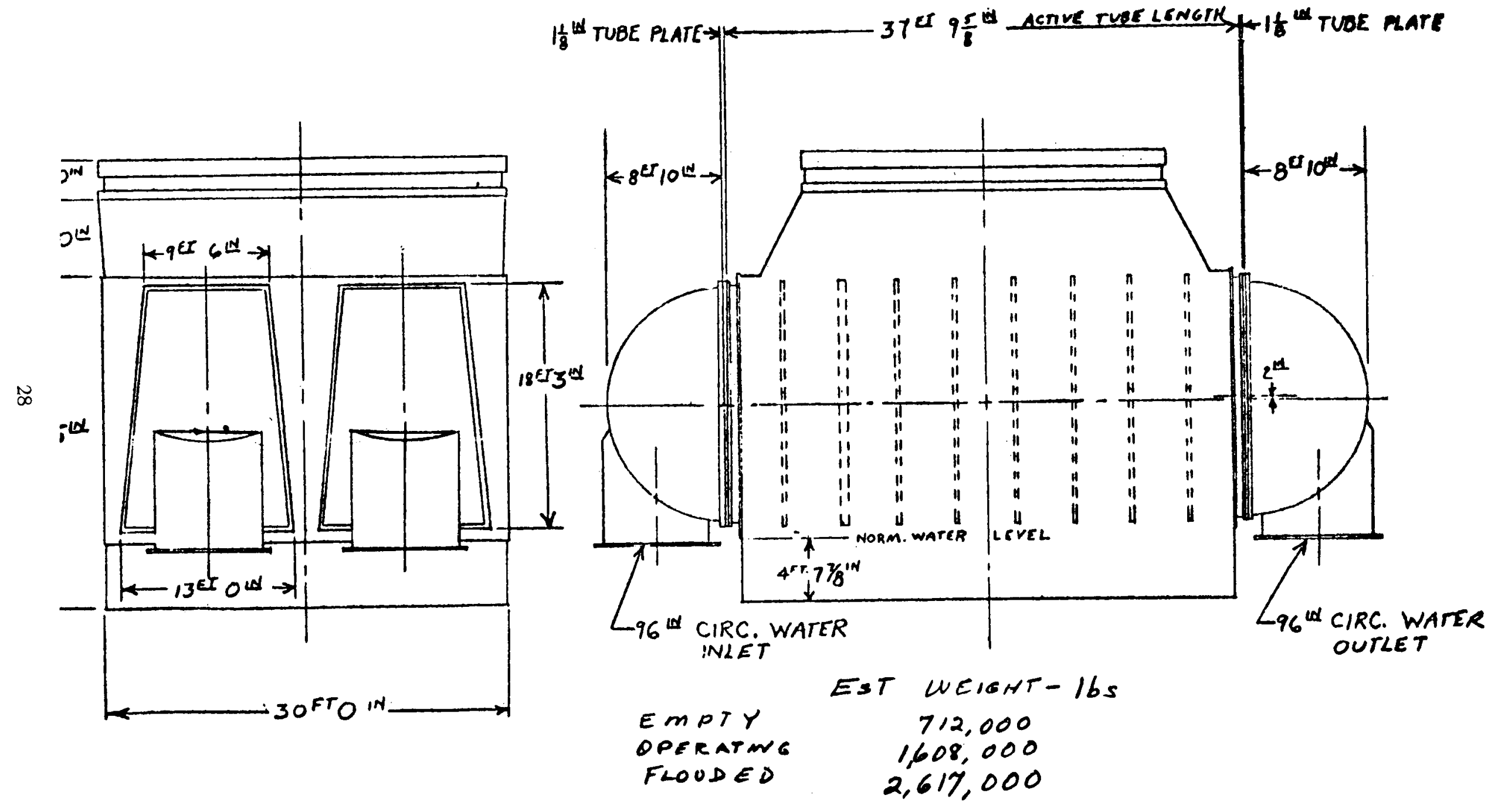

Figure 14. Reheat Plant Condenser 


\section{Air Ejectors}

One G-200 air ejector will be supplied with each condenser. This ejector is similar to the G-150 ejector except that the shell barrel will be 26 inches in diameter, the water nozzles will be 16 inches and the surface area 380 square feet (Figure 15).

Priming Ejector

One P-1200 priming ejector will be supplied for each condenser (Figure 16).

\section{Circulating Water Pumps}

The circulating pumps have been sized for quantity of water specified on the heat balance with no allowance for additional flow. The head was determined by the condenser friction plus 16 feet of external friction. The basic design information is presented in Table 6 and outlines are given in Figures 17 and 18.

\section{TABLE 6}

CIRCULATING WATER PUMP PARAMETERS

\begin{tabular}{|l|c|c|}
\hline & Base Plant & Reheat Plant \\
\hline Type of Pump & $90 \mathrm{BN}$ & $90 \mathrm{BN}$ \\
No. of Pumps/Condenser & 2 & 2 \\
Capacity of Each (gpm) & 173,250 & 170,500 \\
Total Dynamic Head (ft of $\left.\mathrm{H}_{2} \mathrm{O}\right)$ & 26.7 & 26.7 \\
Brake Horsepower (hp) & 1345 & 1323 \\
Speed (rpm) & 294 & 294 \\
\hline
\end{tabular}

\section{Condenser Pumps}

There are two, one-half capacity condensate pumps per condenser with no allowance for conditions which would require additional capacity such as overpressure. If additional capacity is specified, it is possible that a larger pump 

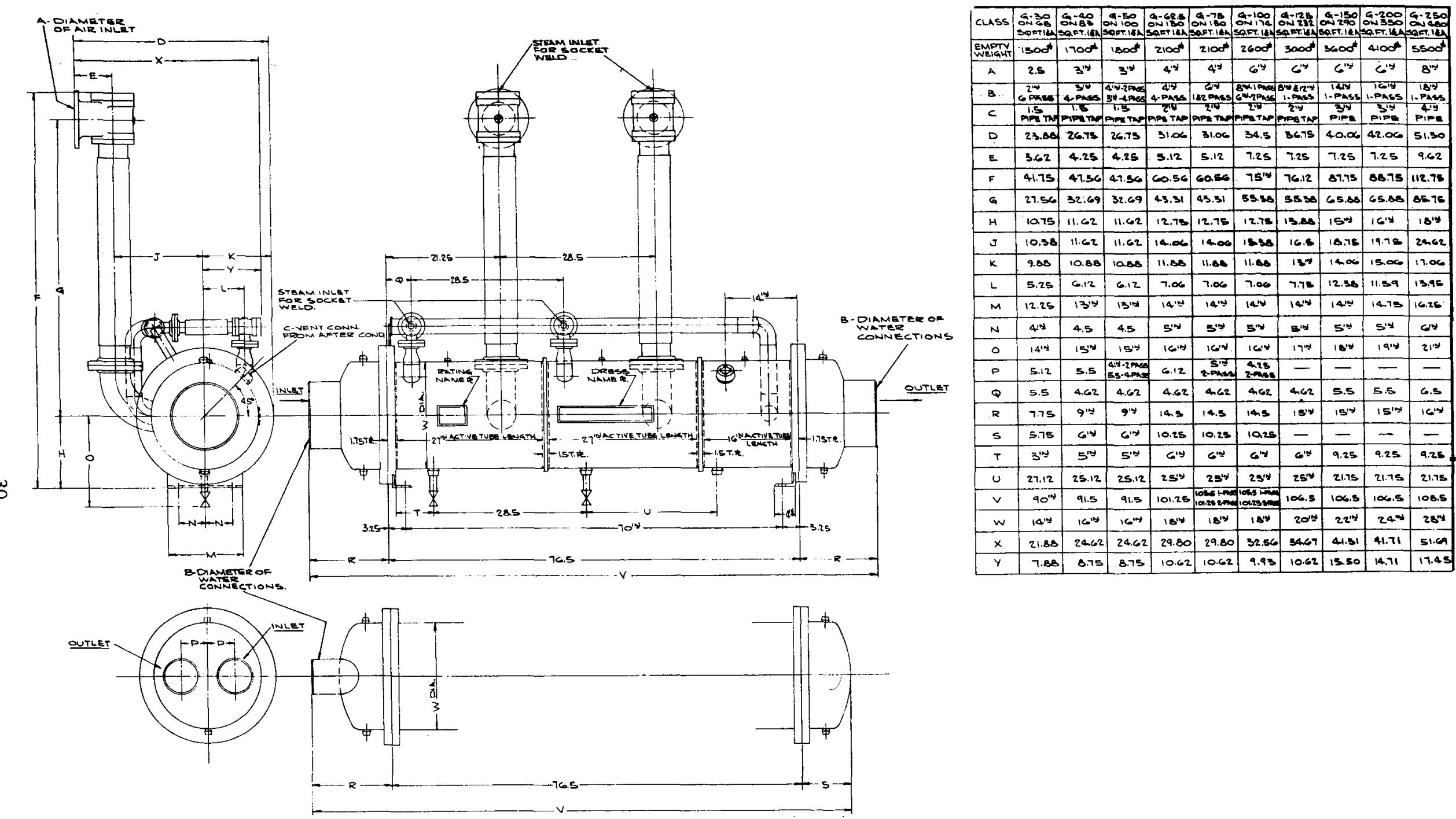

Figure 15. Air Ejector 


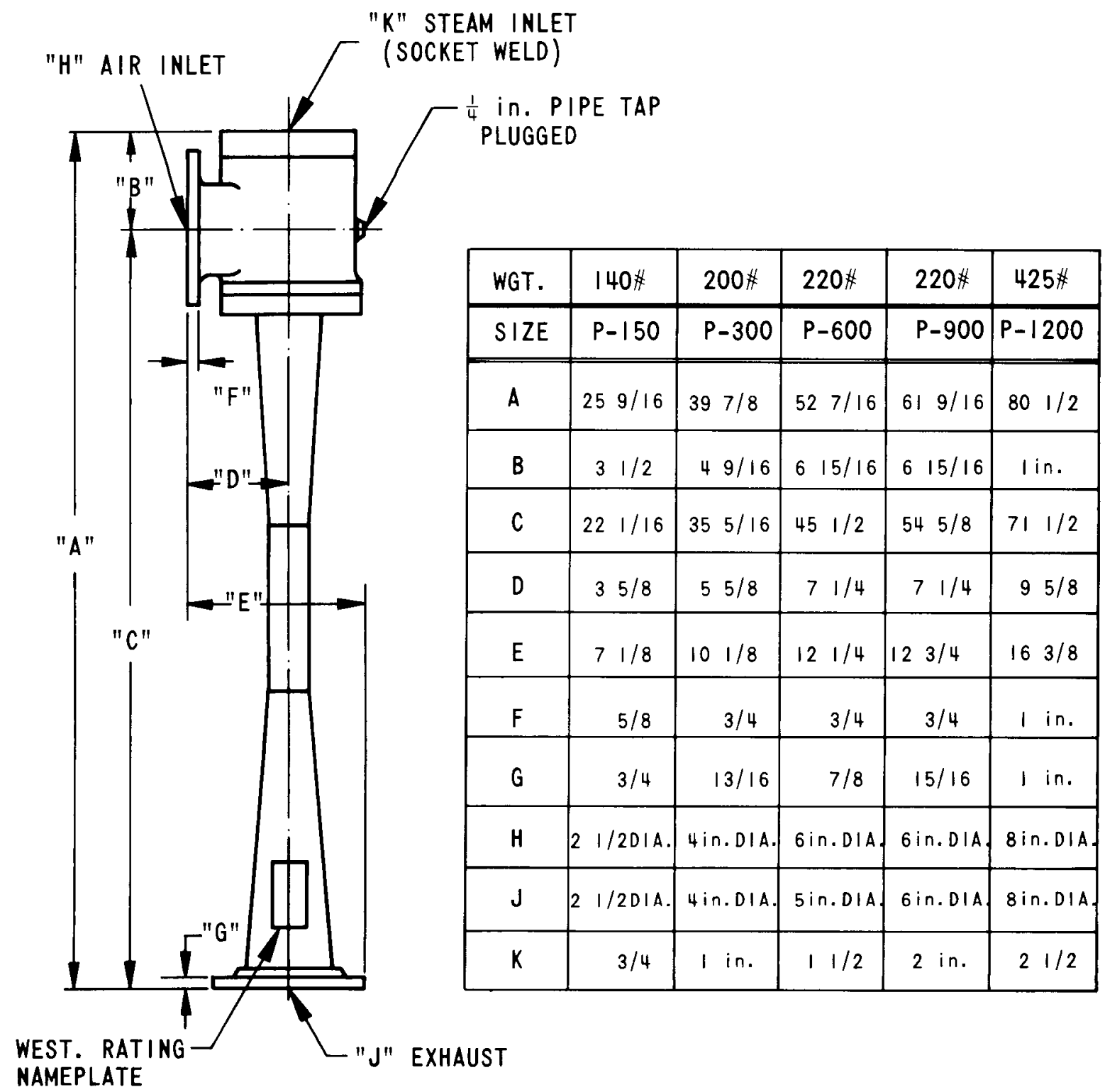

Figure 16. Priming Ejector

3095-3 


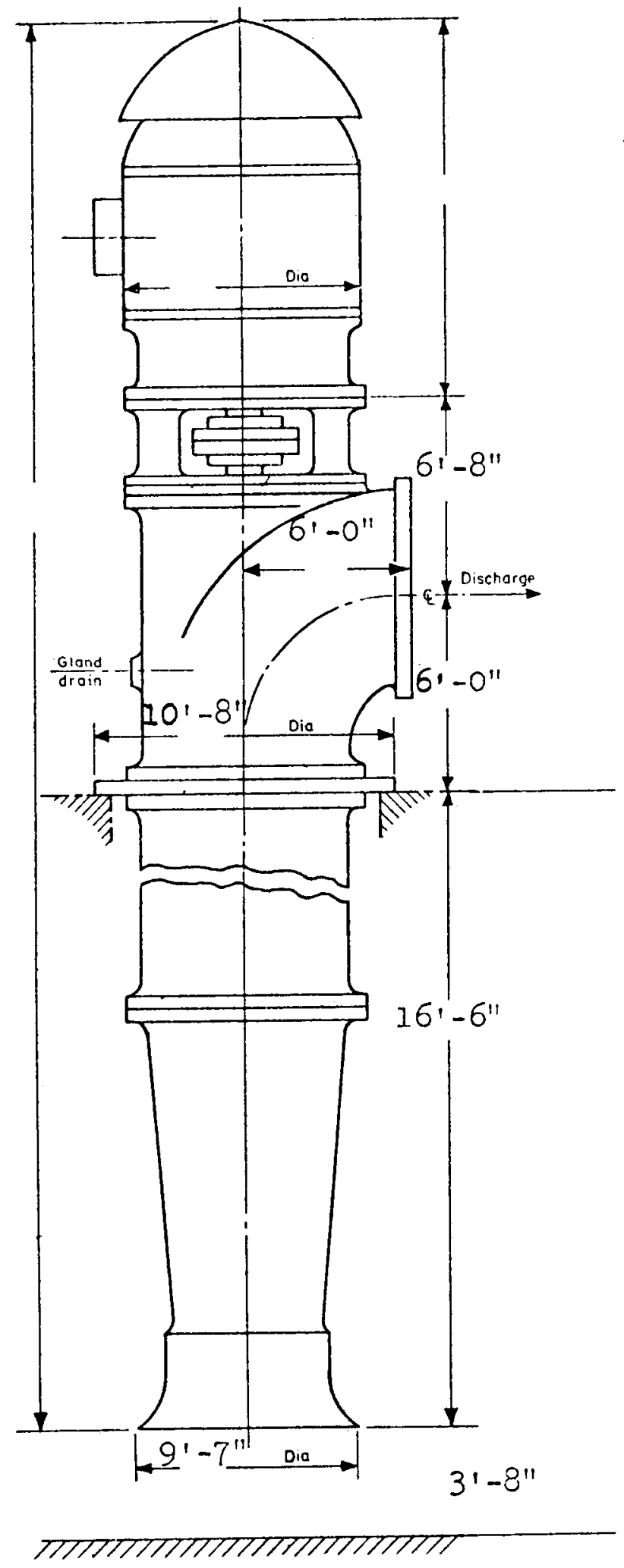

$$
\underset{(C T-20207)}{\operatorname{TYPE} 90} \text { BH }
$$

Ratings

$\begin{array}{rrr}173,250 & \text { gpm } & 26.7 \mathrm{ft} \ldots \mathrm{fdh} \\ 1,345 & \mathrm{fh} & 294\end{array}$

Dimensions are prelminary, and are not to be used for construction purposes.

Discharge diameter_ 90 inches

Elevation $\quad 0$

High water elevation

Normal water elevation

Low water elevatian $6^{\prime}-6^{\prime \prime}$

Down Thrust 34.000 \# Continuous

Estimated Weights

Pump (Less Viotor) $70000 \frac{11}{\pi}$

Elevation $20^{\prime}-2^{\prime \prime}$

Figure 17. Circulating Water Pump (CT-20207) 

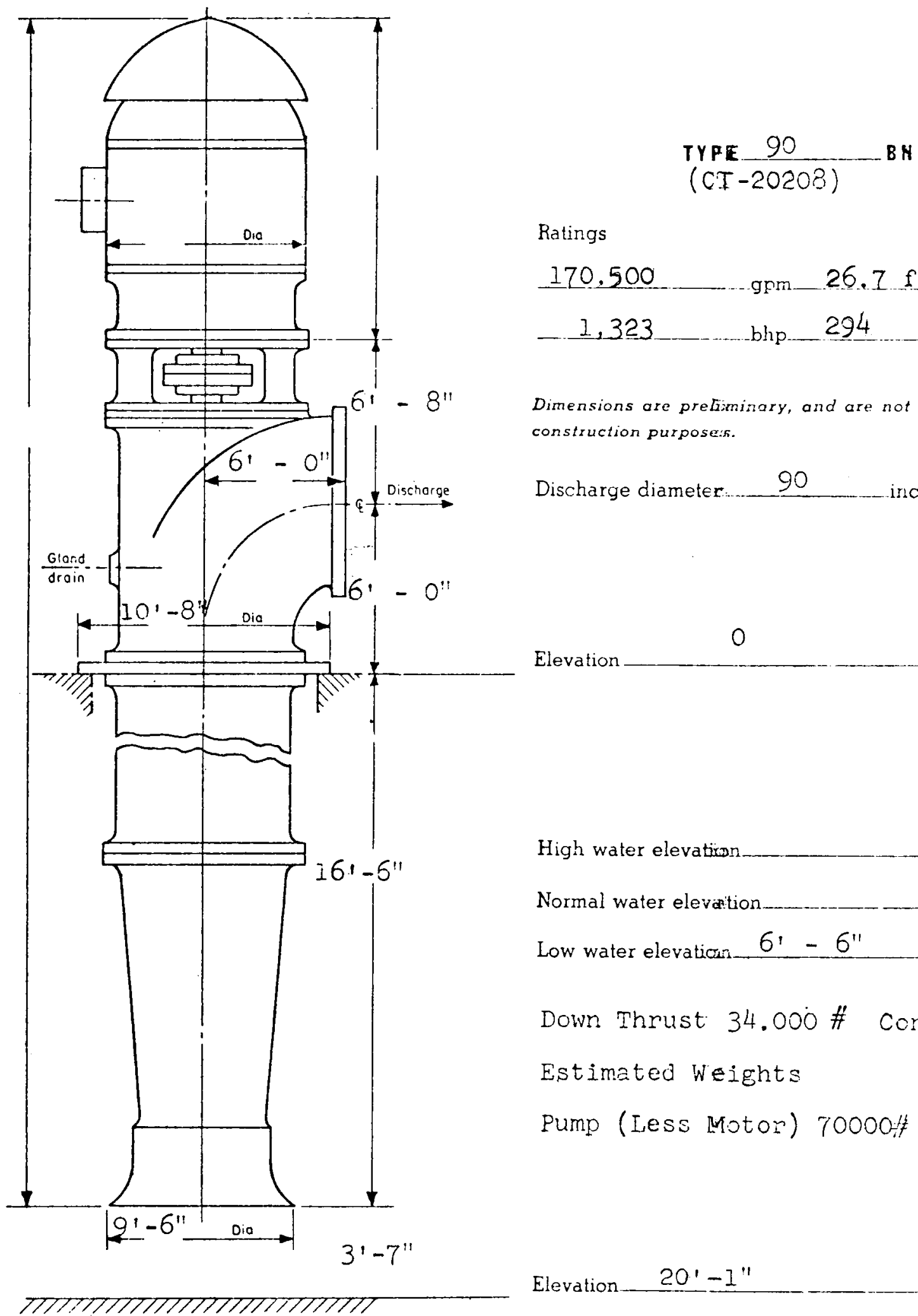

Ratings

$170.500 \quad$ gpm_ $26.7 \mathrm{ft} . \ldots \mathrm{dh}$

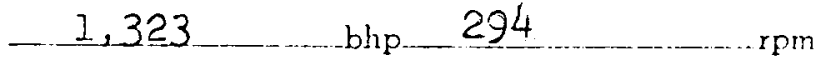

Dimensions are preliminary, and are not to be used for construction purposers.

Discharge diameter $90 \quad$ _._.inches

Elevation

0

High water elevation

Normal water elevation

Low water elevation $6^{\prime}-6^{\prime \prime}$

Down Thrust $34.000^{\circ}$ Continuous

Estimated Weights

Pump (Less Motor) 70000/1

Elevation $20^{\prime}-1^{\prime \prime}$

Figure 18. Circulating Water Pump (CT-20208) 
may be required. The basic design information is presented in Table 7. An outline is given in Figure 19.

TABLE 7

CONDENSATE PUMP PARAMETERS

\begin{tabular}{|l|c|c|}
\hline & Base Plant & Reheat Plant \\
\hline Type of Pump & $123 \mathrm{RW}$ & 123RW \\
No. of Pumps/Condenser & 2 & 2 \\
Capacity of Each (gpm) & 3700 & 3415 \\
Total Dynamic Head (ft of $\mathrm{H}_{2} \mathrm{O}$ ) & 289 & 289 \\
Brake Horsepower (hp) & 345 & 345 \\
Speed (rpm) & 880 & 880 \\
\hline
\end{tabular}

\subsection{Feedwater Heaters}

The feedwater heaters were sized for the conditions specified in the heat balances (Figures 2 and 6 ). Because of the large unit capacity required, a twinstream system was employed. The following ground rules were applied to the design:

\footnotetext{
a. Orientation - all horizontal

b. Length Limits - 45 feet

c. Tubeside Pressure Drop Limit - 12 to 14 psi per heater

d. Shell-Side Design Pressure - Steam pressure plus 15 percent

e. Tubeside Design Pressure - 3500 psi

f. Tube Material - carbon steel - Type 304 stainless steel for FWH in condenser neck

g. Design Temperature for Tubeside and Shell Side - per Feedwater Heaters Manufacturers Association
} 


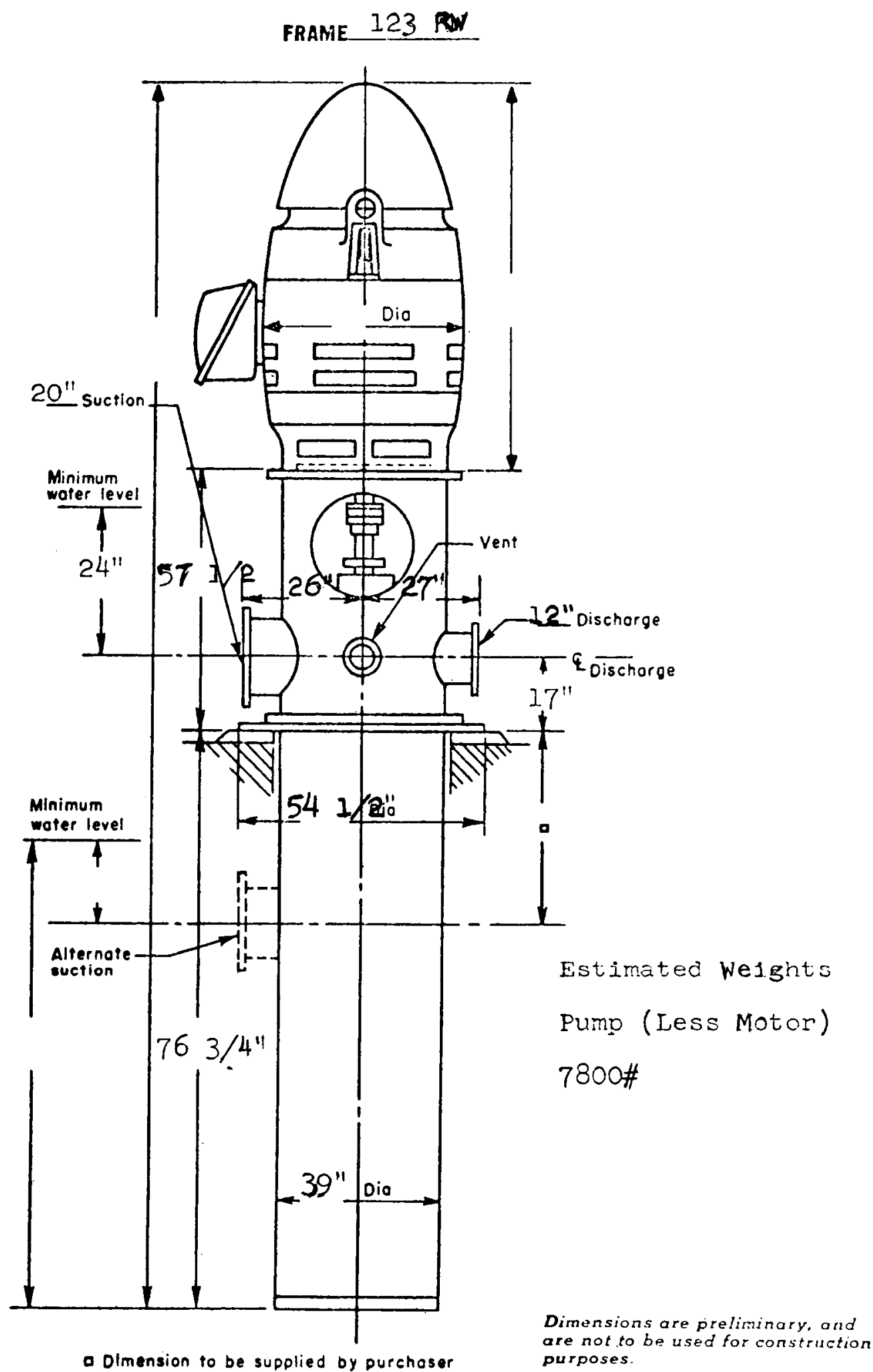

Figure 19. Condensate Pump 
The outline dimensions, nozzle sizes and locations, and weights are presented

in Figures 20 and 21 for the base plant and in Figures 22 and 23 for the reheat plant. 


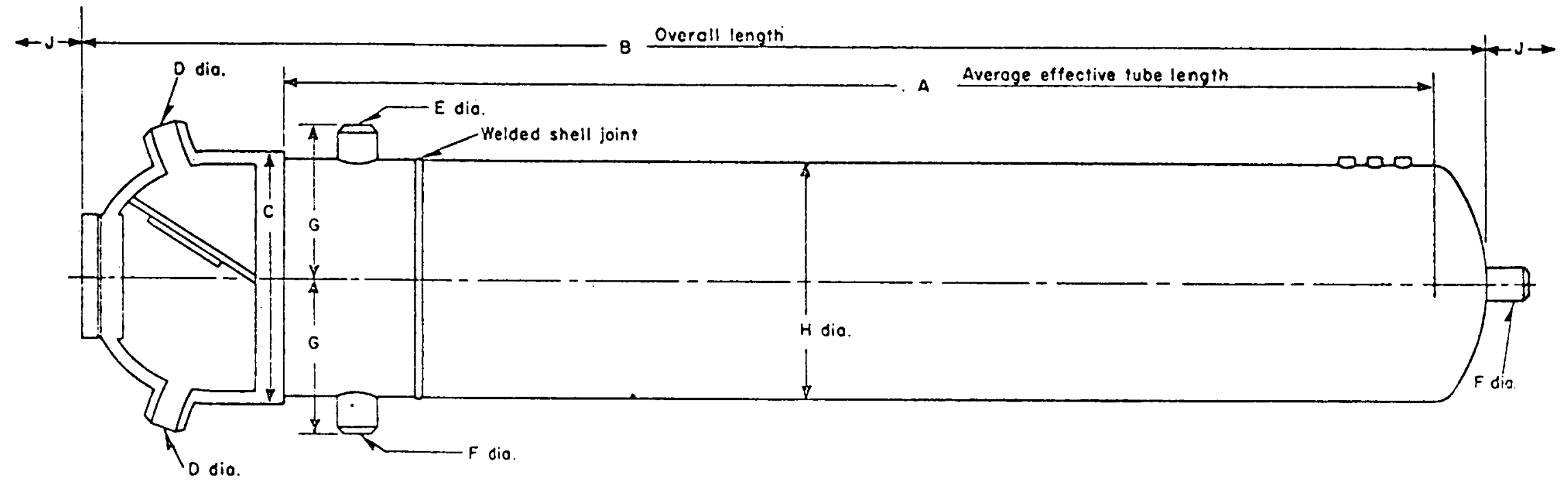

\begin{tabular}{|c|c|c|c|c|c|c|c|c|c|c|}
\hline \multicolumn{11}{|c|}{ DlinEENSIONS } \\
\hline Unit & Area & A & B & C & $D$ & E & $F$ & G & $\mathrm{H}$ & נa \\
\hline Htr : \#I & 26365 & $40.3^{\prime}$ & $45^{\prime}-0^{\prime \prime}$ & $74^{\prime \prime}$ & $18^{\prime \prime}$ & $34^{\prime \prime}$ & $14 "$ & $43^{\prime \prime}$ & $73^{\prime \prime}$ & $39^{\prime}-5^{\prime \prime}$ \\
\hline Htr $\# \neq 2$ & 12700 & $40.3^{\prime}$ & $441-10^{\prime \prime}$ & $64^{\prime \prime}$ & $18^{\prime \prime}$ & $36^{11}$ & $\frac{14}{12^{11}}$ & $\frac{4}{3811}$ & $\frac{13}{63^{11}}$ & $\frac{391-2}{391-811}$ \\
\hline Htr $\# 3$ & 13630 & 40.51 & $45^{\prime}-0^{\prime \prime}$ & $64^{\prime \prime}$ & $18 "$ & (I) $30^{\prime \prime}$ & $10^{11}$ & $38^{\prime \prime}$ & $63^{11}$ & $40^{\prime}-0^{\prime \prime}$ \\
\hline Htr \#4 & 11405 & 39.41 & $43^{\prime}-7^{\prime \prime}$ & $58^{\prime \prime}$ & $18^{\prime \prime}$ & (I) $22^{\prime \prime}$ & $8^{11}$ & $35^{11}$ & $57^{11}$ & $39^{\prime}-2^{\prime \prime}$ \\
\hline
\end{tabular}

- Irstance required for removal of

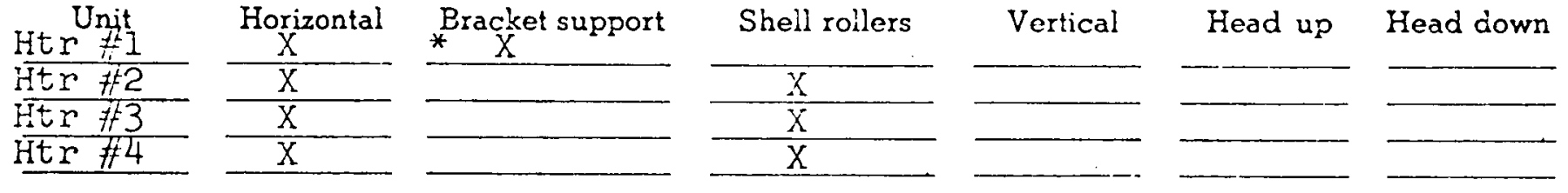

Figure 20. Base Plant Hemispherical Head High Pressure Feedwater Heater $(1,2,3,4)$ 

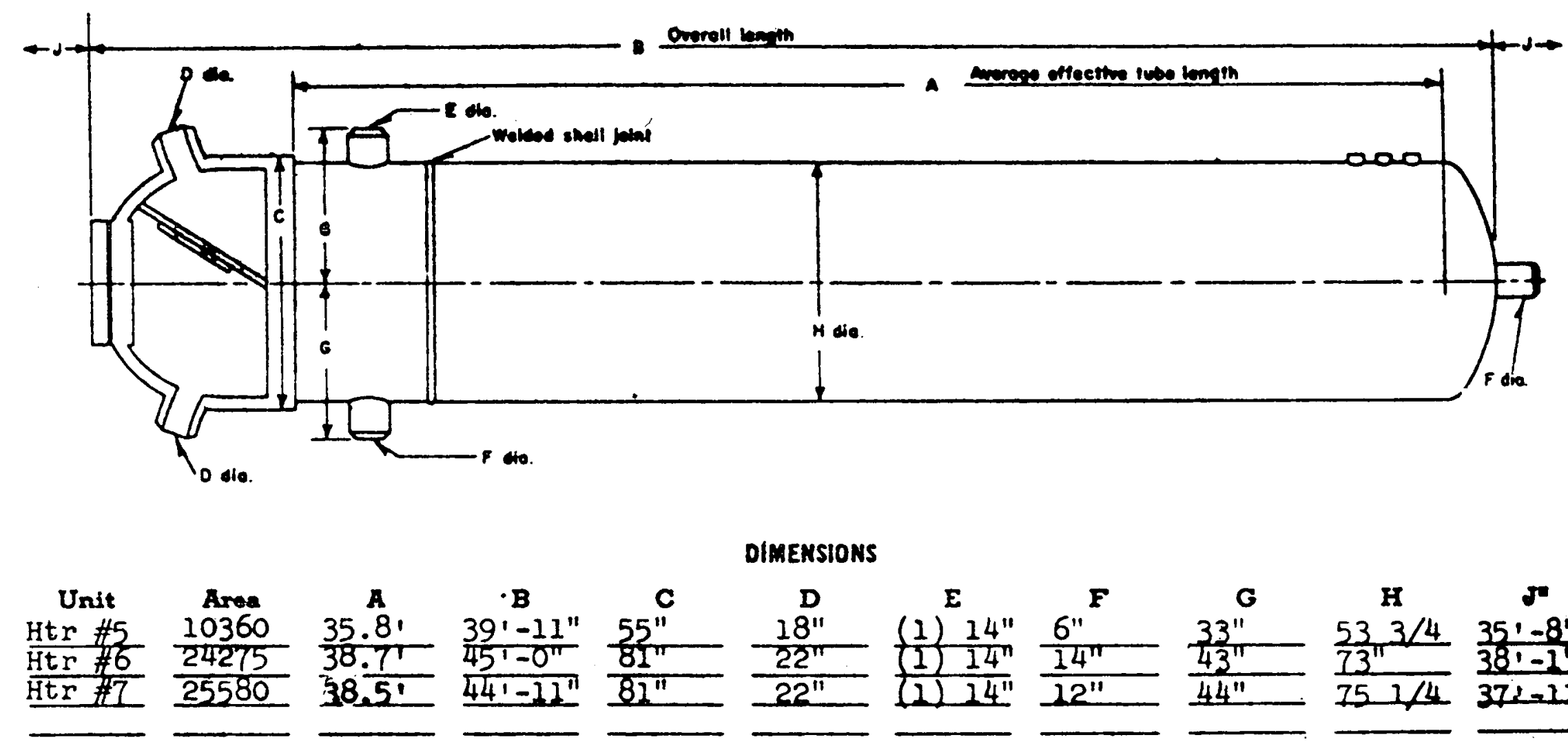

DIBENSIONS
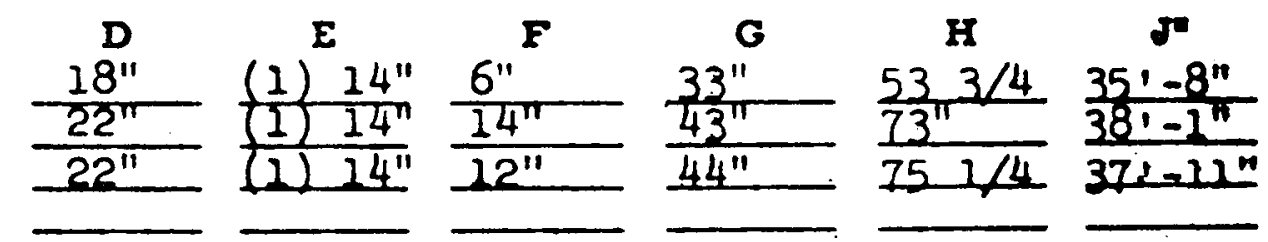

- Duence ropuired bor removal al

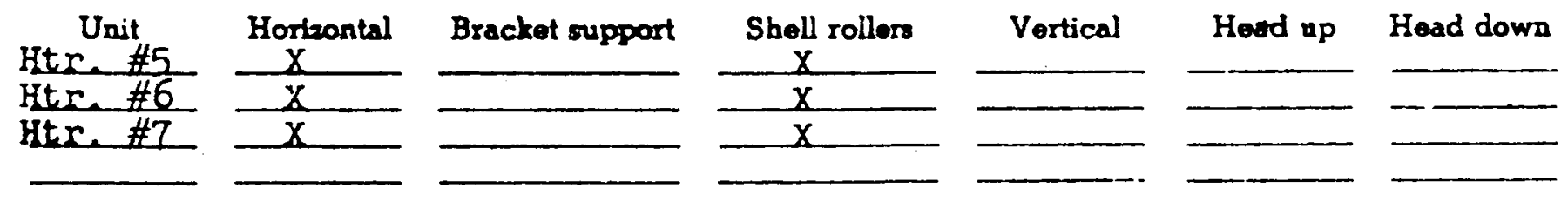

Figure 21. Base Plant Hemispherical Head High Pressure Feedwater Heater $(5,6,7)$ 


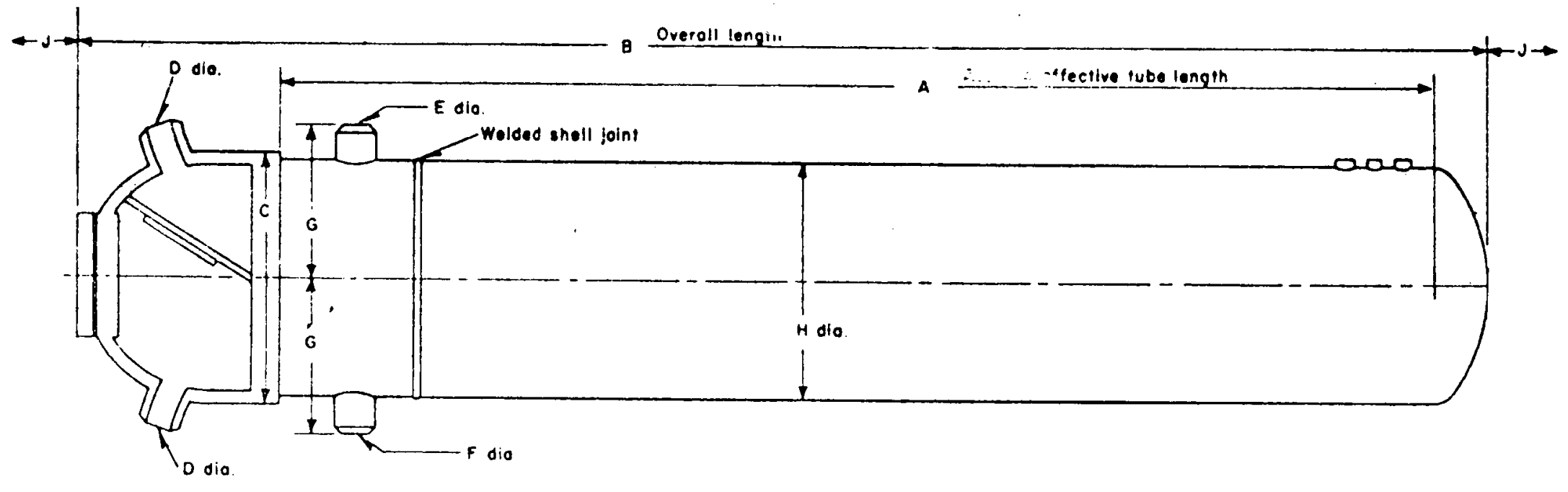

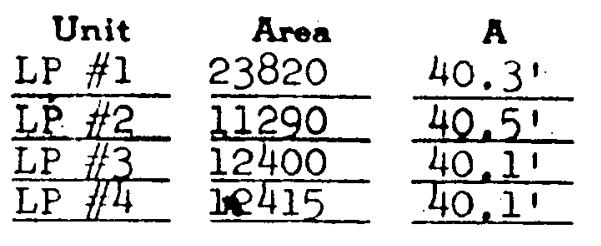

- Dirtance required for remoral of

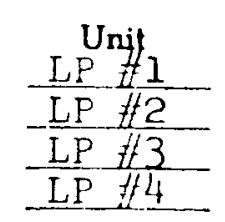

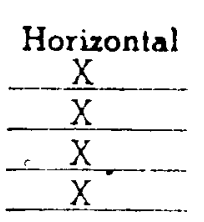

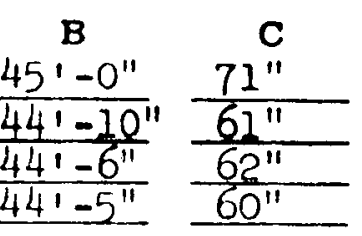

DIMENSIONS

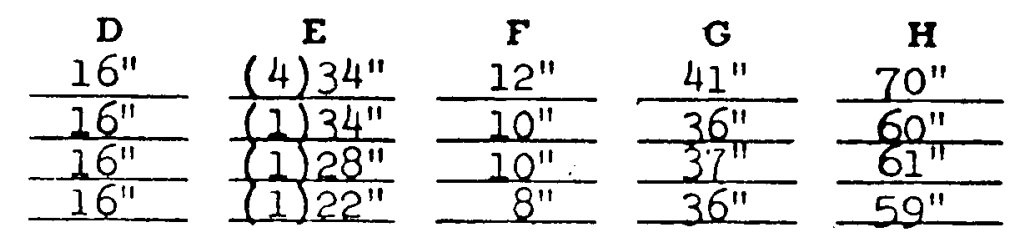

WEIGHTS

Figure 22. Reheat Plant Hemispherical Head High Pressure Feedwater Heater $(1,2,3,4)$ 

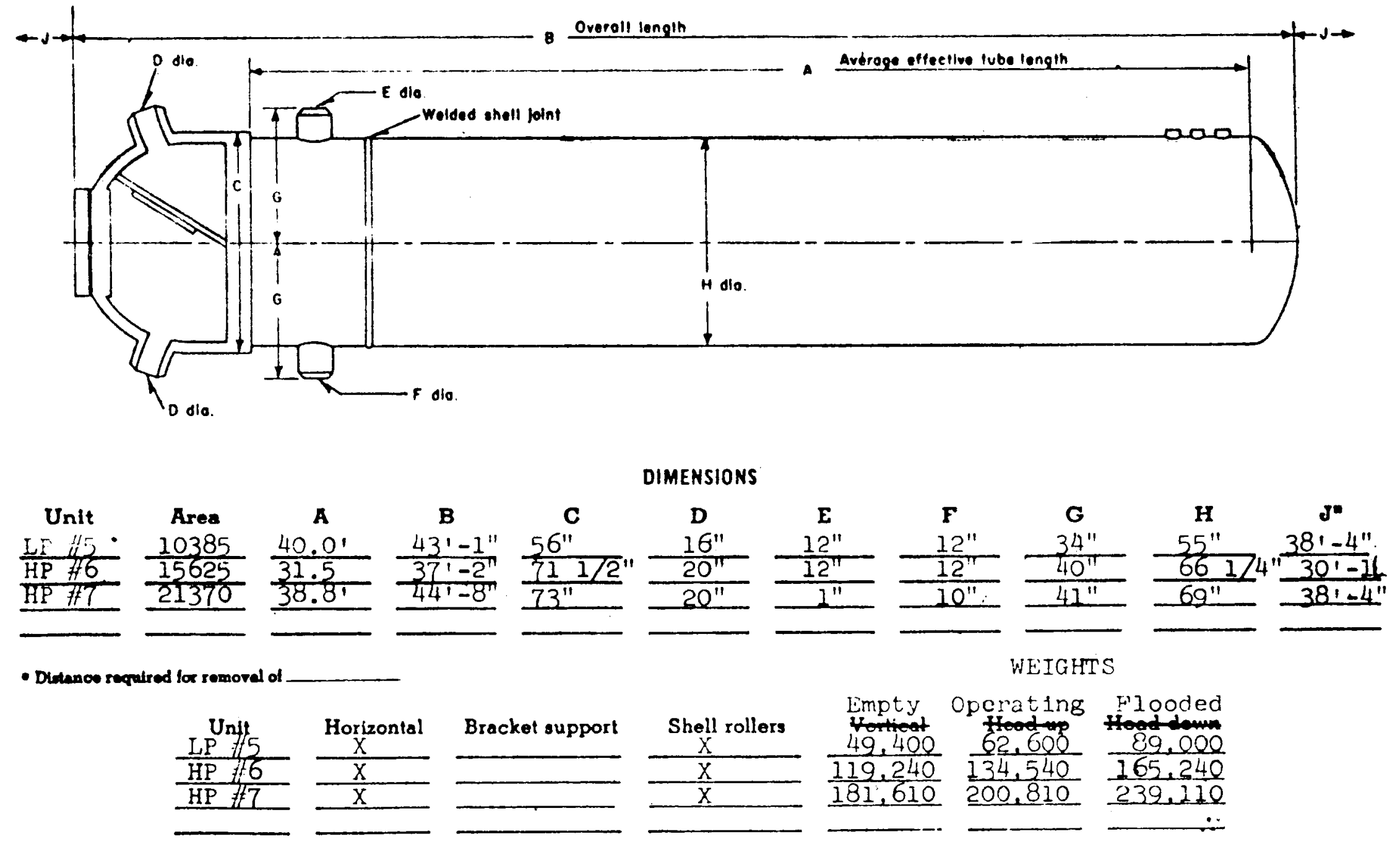

Figure 23. Reheat Plant Hemispherical Head High Pressure Feedwater Heater $(5,6,7)$ 


\section{SECTION 5}

STEAM GENERATORS AND REHEATERS

The Westinghouse sodium-heated steam generator concept has been described elsewhere. [4] Briefly, the units employed here comprise six separate serpentine tube bank modules resting in a vertical cylindrical shell with hemispherical heads. Six hemispherical inlet feedwater headers are arranged on the bottom head periphery and the six steam discharge headers are near the top of the unit shell.

The reheater is of the same general construction as the steam generator, but uses different tube sizes and materials. Table 8 presents a tabulation of the principal parameters.

The reheat concept is a modification of the base scheme which does not affect the primary system or the reactor containment building.

The secondary loops are modified by extending the steam generator bay an additional 30 feet to accommodate the separate reheaters and the somewhat smaller steam generators.

The reheater and steam generator in each sodium loop are piped in parallel with a flow control valve in the reheater flow path to adjust the flow ratio and thus control reheat temperature. The total sodium flow rate in the secondary loop is 92 million pounds-per-hour as in the base scheme and therefore the sodium pumps and intermediate heat exchangers (IHX's) are unchanged.

The addition of the reheater does increase the sodium inventory slightly and the estimates reflect this increase in both initial sodium charge and storage requirement. All other sodium auxiliary systems are unaffected. 
TABLE 8

SODIUM-HEATED STEAM GENERATOR AND REHEATER PARAMETERS

\section{Genera1}

Number of Units

Unit Type

Unit Rating (MWt)

Dry Weight (1b)

Overall Length ( $f t$ )

Distance between Shell Nozzles

Overall Diameter (ft)
Base Plant Steam Generator

2

Once-through, Counter-Flow, shel1 and tube type 1300

600,000

65.0

(ft) 44.3

15.0
1100

540,000

64.5

44.1

14.58
Reheat Plant

\section{Reheater}

2

2 420,000

53.0

32.3

15.0

\section{She11 Side}

Fluid

Flow Rate $\left(10^{6} 1 \mathrm{~b} / \mathrm{hr}\right)$

Sodium

46.0

Inlet Temperature $\left({ }^{\circ} \mathrm{F}\right)$

Outlet Temperature $\left({ }^{\circ} \mathrm{F}\right)$

Design Temperature $\left({ }^{\circ} \mathrm{F}\right)$

Inlet Pressure (psia)

Design Pressure (psi)

Flow Pressure Drop (psi)

Shell Hold-up ( $f \mathrm{t}^{3}$ )

Shell Inlet Nozzle Diameter (2) (in) 30

Shell Outlet Nozzle Diameter (2)(in) 30

Material
Sodium

38.2

965

650

1000

32.3

200

11.0

5500

26

26

304 SS
Sodium

7.8

965

650

1000

39.3

200

11.0

5700

14

14

304 SS 
TABLE 8 (Cont)

SODIUM-HEATED STEAM GENERATOR AND REHEATER PARAMETERS

Tube $\underline{\text { Side }}$

Base Plant

Reheat Plant

Fluid

Flow Rate $\left(10^{6} \mathrm{lb} / \mathrm{hr}\right)$

$\underline{\text { Steam Generator Steam Generator }}$ Reheater

Inlet Temperature $\left({ }^{\circ} \mathrm{F}\right)$

Water/Steam

Steam

Outlet Temperature $\left({ }^{\circ} \mathrm{F}\right)$

$$
4.91
$$

3.27

3.69

500

500

596

903

903

900

Design Temperature $\left({ }^{\circ} \mathrm{F}\right)$

1000

1000

1000

Inlet Pressure (psia)

2660

2660

685

Design Pressure (psi)

3000

3000

800

Flow Pressure Drop (psi)

225

225

30

\section{Genera1}

Number of Tubes

3600

3240

2100

Effective Tube Outside Surface $\left(\mathrm{ft}^{2}\right)$

58,500

53,000

39,000

Tube Outside Diameter (in)

0.50

0.50

1.00

Tube Wall Thickness (in-min)

0.065

0.065

0.042

Square Pitch (in)

1.00

1.00

1.375

Effective Tube Length ( $f t$ )

124

125

71

Tube Side Hold-up ( $\mathrm{ft}^{3}$ )

480

Tube Inlet Nozzle Diameter (6)(in) 8

450

1015

Tube Outlet Nozzle Diameter (6)(in) 12

6

16

10

16

Material

Incoloy 800

Incoloy 800

304 SS 


\section{SECTION 6}

\section{PLANT CAPITAL PRICE}

The preliminary design and plant capital cost is based upon the Middletown site. The AEC Guide to Nuclear Power Cost Evaluation [3] is used where practical. U-E performed the plant construction design and costs. WHTD performed the design and estimated the price of the steam generators, reheaters, condensers and feedwater heaters. WLTD performed the heat balance and supplied book prices for the turbine-generator units.

Estimated turbine plant costs are based principally upon data developed by U-E for the 1966 study [5] performed for Argonne National Laboratory adjusted to the October 1, 1967 price level. Also, data has been adjusted for the specific machines and cycle arrangements presented on the Westinghouse heat balance diagrams and machine outline drawings. A cross-compound, four-flow with 44-inch, low pressure, last-row blading (CC4F-44) reheat machine with steam conditions of 2415 psia $900 / 900^{\circ} \mathrm{F}$ was compared to a tandem-compound, four-flow with 44inch, low-pressure, last-row blading (TC4F-44) non-reheat machine with steam conditions of 2415 psia $900^{\circ} \mathrm{F}$. Both cycles contemplate steam driven boiler feed pumps. Accordingly, U-E have re-estimated the turbine plant buildings to reflect the permissible shortening of the turbine hall associated with the elimination of the shaft driven pumps.

Subsequent to 1966 , U-E's position concerning condensate polishing for installation using fresh water for condenser cooling has been revised. They are now recommending the use of POWDEX systems only, rather than precoated filters plus deep bed demineralizers. Cost of service facilities and condensate polishing systems have been adjusted to reflect this change in the basic design concept. The costs are specific for the condensate flows presented on the Westinghouse heat balances. 
Cost of main feed pumps reflects actual bid prices received by U-E for identical discharge pressure requirements that have been adjusted to meet Westinghouse boiler feed pump flow requirements.

Condenser erection labor and circulation water piping systems screen well structure and associated equipment were estimated for the condensers.

Turbine plant piping estimate was reviewed not only from the viewpoint of the heat balances requirement but also was updated to reflect U-E's latest estimate of piping associated with moisture separators and low-pressure turbine intercept valve requirements. In the latter category, U-E now include safety valve vent piping and a major drains system associated with the moisture separators. The erection labor cost estimate for the closed heater reflects the elimination of a deaerator from the cycle and the inclusion of seven heaters.

Costs for accessory electrical equipment have been adjusted to reflect specific motor loads anticipated for the primary and secondary system sodium pumps. For this equipment, U-E have used handbook prices to develop estimated cost. All erection labor has been estimated by U-E at present day rates for a Western Massachusetts site.

The above estimates give direct cost of major buildings, equipment and systems affected by going from moisture separation plants to reheat. To allow for contingency, administration, engineering, etc. an adder of 45 percent was used for the reactor plant and 35 percent for the turbine plant. These costs and prices are presented in Table 9. 
TABLE 9

CAPITAL ITEMS AFFECTED BY MOISTURE SEPARATION

OR SODIUM REHEAT CYCLES*

SUMMARY

Acct.

No.

\section{9}

221

222

225

$212 \mathrm{~A}$

227

231

241

251
Turbine Building

Feedwater Supply and Treatment

Turbine Generator Plant

Generator Main \& Neutral Circuit

Turbine Room Crane

Total Direct Turbine Plant Cost

Indirect Turbine Plant Cost

Estimated Turbine Plant Price

(Items Affected)

Total Plant Price (Items Affected)

Differential
Moisture

Separation

Sodium Reheat

\begin{tabular}{rr}
7,315 & 7,570 \\
659 & 665 \\
18,834 & 24,745 \\
9 & 12 \\
\hline 26,817 & 32,992 \\
$\underline{12,068}$ & $\underline{14,846}$ \\
38,885 & 47,838
\end{tabular}

3,379

3,181

4,236

3,685

32,502

31,034

298

357

268

240

40,710

38,497

14,248

13. 474

54,958

51,971

93,843

99,809

Base
5,966

*Cost and prices in thousands of dollars. 
CAPITAL ITEMS AFFECTED BY MOISTURE SEPARATION OR SODIUM REHEAT CYCLES

\begin{tabular}{|c|c|c|c|}
\hline $\begin{array}{l}\text { Acct. } \\
\text { No. }\end{array}$ & Description & $\begin{array}{l}\text { Moisture } \\
\text { Separation }\end{array}$ & $\begin{array}{l}\text { Sodium } \\
\text { Reheat }\end{array}$ \\
\hline \multirow[t]{11}{*}{219} & Reactor Containment Structure & & \\
\hline & Excavation & 208 & 236 \\
\hline & Substructure Concrete & 1216 & 1280 \\
\hline & Substructure Reinf. Steel & 1555 & 1612 \\
\hline & Substructure Insulating Concrete & 86 & 96 \\
\hline & Superstructure Concrete & 600 & 600 \\
\hline & Superstructure Reinf. Steel & 767 & 767 \\
\hline & Superstructure Struc. Steel & 135 & 157 \\
\hline & Siding and Roofing & 194 & 228 \\
\hline & Liner Plate & $\underline{2554}$ & 2594 \\
\hline & 219 Total & 7315 & 7570 \\
\hline \multirow[t]{9}{*}{221} & Reactor Equipment & & \\
\hline & Reactor Shielding & & \\
\hline & Shield Cooling System & 134 & 140 \\
\hline & Reactor Plant Cranes & & \\
\hline & Reactor B1dg. Crane & 245 & 245 \\
\hline & Pump Bay Crane & 90 & 90 \\
\hline & Maintenance Cell Inside & 60 & 60 \\
\hline & Outside & $\underline{130}$ & $\underline{130}$ \\
\hline & 221 Total & 659 & 665 \\
\hline
\end{tabular}


TABLE 9 (Cont)

CAPITAL ITEMS AFFECTED BY MOISTURE SEPARATION OR SODIUM REHEAT CYCLES

\begin{tabular}{|c|c|c|c|}
\hline $\begin{array}{l}\text { Acct. } \\
\text { No. }\end{array}$ & Description & $\begin{array}{l}\text { Moisture } \\
\text { Separation }\end{array}$ & $\begin{array}{l}\text { Sodium } \\
\text { Reheat }\end{array}$ \\
\hline \multirow[t]{29}{*}{222} & Heat Transfer Systems & & \\
\hline & Reactor Coolant System & & \\
\hline & Primary Pumps & 2950 & 2950 \\
\hline & Heat Wrap & 24 & 24 \\
\hline & Insulation & 10 & 10 \\
\hline & Pipe & 307 & 307 \\
\hline & Insulation & 67 & 67 \\
\hline & Heat Wrap & 28 & 28 \\
\hline & Intermediate Cooling System & & \\
\hline & Secondary Pumps & 1815 & 1815 \\
\hline & Heat Wrap & 19 & 19 \\
\hline & Insulation & 8 & 8 \\
\hline & Piping and Valves & & \\
\hline & Pipe & 264 & 320 \\
\hline & Valves & 249 & 353 \\
\hline & Insulation & 65 & 89 \\
\hline & Heat Wrap & 27 & 37 \\
\hline & Intermediate Heat Exchanger & & \\
\hline & IHX & 3875 & 3875 \\
\hline & Heat Wrap & 13 & 13 \\
\hline & Insulation & 31 & 31 \\
\hline & Steam Generators & & \\
\hline & Steam Generators & 8401 & 7739 \\
\hline & Heat Wrap & 22 & 21 \\
\hline & Insulation & 52 & 50 \\
\hline & Reheaters & & \\
\hline & Reheaters & --- & 6025 \\
\hline & Heat Wrap & --- & 18 \\
\hline & Insulation & --- & 42 \\
\hline
\end{tabular}


TABLE 9 (Cont)

CAPITAL ITEMS, AFFECTED BY MOISTURE SEPARATION OR SODIUM REHEAT CYCLES Acct.

No

Description

Moisture

Sodium

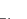

222 (Cont) Heat Transfer Systems

Primary and Intermediate Coolant

Coolant Receiving and Storage

Primary Coolant

Separation

Reheat

Secondary Coolant

Base

100

342

342

265

$\underline{462}$

222 Total 18,834

24,745

225

Radioactive Waste Treatment

Primary Drain and Vent System

Intermediate Drain and Vent System

9

9

Base

3

225 Tota 1

9

12

$212 \mathrm{~A}$

Turbine Building

Substructure

551

514

Superstructure

2115

1972

Service Facilities

713

695

212A Total

3379

3181

227

Feedwater Supply and Treatment

Condensate Polishing System

535

497

Feedwater Heaters

Closed Heaters

1829

1589

Insulation

78

75

Feedwater Pumps and Drives

Pumps

639

550

Drives

1182

974

227 Total

4263

3685 
TABLE 9 (Cont)

CAPITAL ITEMS AFFECTED BY MOISTURE SEPARATION OR SODIUM REHEAT CYCLES

\begin{tabular}{|c|c|c|c|}
\hline $\begin{array}{l}\text { Acct. } \\
\text { No. }\end{array}$ & Description & $\begin{array}{l}\text { Moisture } \\
\text { Separation }\end{array}$ & $\begin{array}{l}\text { Sodium } \\
\text { Reheat }\end{array}$ \\
\hline \multirow[t]{14}{*}{231} & Turbine Generator Plant & & \\
\hline & Generator Foundation & & \\
\hline & Concrete Fnd., Mat \& Piles & 220 & 242 \\
\hline & Support above Fnd. Mat. & 507 & 578 \\
\hline & Turbine Generators & & \\
\hline & Turbogenerators & 25,014 & 23,904 \\
\hline & Lube-0il Equipment & 80 & 87 \\
\hline & Condensers & 2391 & 2359 \\
\hline & Turbine Plant Piping & & \\
\hline & Main Reheat \& Extra Steam & 1378 & 1523 \\
\hline & Condensate $\&$ Feedwater & 1762 & 1490 \\
\hline & Cooling Water, etc. & 782 & 578 \\
\hline & Service Water, etc. & 368 & 273 \\
\hline & 231 Total & 32,502 & 31,034 \\
\hline \multirow[t]{2}{*}{241} & Generator Main \& Neutral Cir. & & \\
\hline & Isolated Phase Bus & 298 & 357 \\
\hline 251 & Turbine Room Crane & 268 & 240 \\
\hline
\end{tabular}


SECTION 7

EVALUATION OF CYCLES

\subsection{TECHNICAL FACTORS}

There is a combination of technical and economic factors to consider in evaluating the reheat and moisture separation cycle. A reheat plant is basically more complex; therefore, the only valid reason for going to additional complications is for a resulting lower power cost. The reheat plant has a higher efficiency than the moisture separation plant; therefore, a smaller reactor plant is required to generate the same amount of power with reheat.

Some complicating features in the reheat plant were not economically evaluated in the study. These are:

a. Reduced plant reliability due to reheaters and flow control valves

b. More elaborate plant start-up system and procedure

c. More complicated plant control system

d. Additional reheater development work

e. Additional maintenance due to reheaters and flow control valves

Apart from the above points, operation of both the reheat plant and moisture separation plant are the same.

\subsection{ECONOMIC FACTORS}

\subsubsection{Capital Price}

The scope of the study in Task I was such that the capital price of the complete plant was not priced. Only those items were priced which vary with the concept. The designs were based on the same reactor plant output of 2600-MWt; therefore the two cycles had a different net electrical output. This amounted to 1045MWe for the moisture separation plant and 1072-MWe for the reheat plant. 
To determine the power cost difference due to capital costs of the two plants (reheat minus moisture separation), the following expression was derived:

$$
\Delta \mathrm{f}_{\mathrm{p}}=\left(\frac{0.13}{7}\right)\left\{\mathrm{m}\left[\left(\frac{\mathrm{H}_{\mathrm{r}}}{\mathrm{H}_{\mathrm{r}}+\Delta \mathrm{H}}\right)^{\eta}-\mathrm{I}\right]+\left(\frac{\mathrm{H}_{\mathrm{r}}}{8874}\right)^{n} \mathrm{R}\right\}
$$

where:

$$
\begin{aligned}
\Delta \mathrm{f}_{\mathrm{p}}= & \text { the differential power cost due to capital costs (reheat minus } \\
& \text { moisture separation) (mill/kWh) } \\
\mathrm{m}= & \text { the unit capital price of the moisture separation plant }(\$ / \mathrm{kW}) \text { ex- } \\
& \text { clusive of customer costs } \\
\mathrm{H}_{\mathrm{r}}= & \text { the net plant heat rate of the reheat plant (Btu/kWh) } \\
\mathrm{H}_{\mathrm{r}}+\Delta \mathrm{H}= & \text { the net plant heat rate of the moisture separation plant }(\mathrm{Btu} / \mathrm{kWh)} \\
\mathrm{R}= & \text { the additional cost of the Reheat plant over the Moisture Separation } \\
& \text { plant }\left(\$ 10^{6}\right) \\
n= & \text { size-price relationship exponent }
\end{aligned}
$$

In the above equation, a plant annual operating factor of 80 percent $(7,000$ hours per year) was assumed, together with an annual capital charge of 13 percent. Since $\mathrm{m}$ and $\mathrm{n}$ were not known, nor are they likely to be known very soon, a wide range of values was assumed -

$$
120-160 \$ / \mathrm{kW} \text { for } \mathrm{m} \text { and } 0.60 \text { to } 0.80 \text { for } \mathrm{n}
$$

The differential power cost due to capital are shown in Table 10 with the corresponding values of $\mathrm{m}$ and $\mathrm{n}$.

The actual differential heat rate between the two plants is not great. This makes the moisture separation cycle a worthwhile possibility, since unit plant capital cost $(\$ / \mathrm{kW})$ is directly proportional to heat rate. An investigation of the heat rate effect on the differential power cost was also made. Table 10 shows the differential power cost due to capital if the net heat rate was $8874 \mathrm{Btu} / \mathrm{kWh}(\Delta \mathrm{H}=593)$. It must be emphasized that the turbine cycle heat rates are quite accurate. As a matter of fact, it would be possible to order the turbine-generator and heat transfer equipment from Westinghouse now, with performance as stated in the report. 
TABLE 10

DIFFERENTIAL POWER COSTS DUE TO CAPITAL REHEAT

MINUS MOISTURE SEPARATION, $\triangle \mathrm{f}$

\begin{tabular}{|c|c|c|c|}
\hline $\begin{array}{c}\text { Capital Price } \\
\mathrm{m} \\
(\$ / \mathrm{kW})\end{array}$ & $\begin{array}{c}\text { Size-Price } \\
\text { Exponent } \\
n\end{array}$ & $\begin{array}{c}\Delta f_{p} \\
m i 11 / k W h \\
(\Delta H=209)\end{array}$ & $\begin{array}{c}\Delta \mathrm{f} \\
\mathrm{p} \\
(\mathrm{mill} / \mathrm{kWh}) \\
\text { (if } \Delta \mathrm{H}=593)\end{array}$ \\
\hline \multirow[t]{3}{*}{120} & 0.60 & 0.075 & +0.0175 \\
\hline & 0.70 & 0.068 & +0.0020 \\
\hline & 0.80 & 0.062 & -0.0135 \\
\hline \multirow[t]{3}{*}{140} & 0.60 & 0.069 & +0.0020 \\
\hline & 0.70 & 0.062 & -0.0156 \\
\hline & 0.80 & 0.055 & -0.00336 \\
\hline \multirow[t]{3}{*}{160} & 0.60 & 0.064 & -0.0132 \\
\hline & 0.70 & 0.055 & -0.0332 \\
\hline & 0.80 & 0.047 & -0.0535 \\
\hline
\end{tabular}

$\mathrm{H}_{\mathrm{r}}=8281 \mathrm{Btu} / \mathrm{kWh} ; \mathrm{R}=6.1\left(\$ 10^{6}\right)$

\subsubsection{Fuel Cost}

Fuel cycle costs have not been established for this plant; moreover, there is a possibility for fuel cycle cost improvement. Thus it was decided to examine the effect of power costs due to fuel over a range of 7 to 16 cents per million Btu. This corresponds to a fuel cost range of about 0.6 to 1.4 $\mathrm{mill} / \mathrm{kWh}$ which is approximately the range of expected fuel costs.

Let $\Delta \mathrm{f}_{\mathrm{m}}$ be the differential power cost due to fuel (mill/kWh)

$\mathrm{f}_{c}$ be the fuel cost $\left(c / 10^{6} \mathrm{Btu}\right)$

$\Delta \mathrm{H}$ be the differential plant net heat rate (Btu/kWh) 
Then,

$$
\Delta \mathrm{f}_{\mathrm{m}}=\mathrm{f}_{\mathrm{c}} \times 10^{-5} \Delta \mathrm{H}
$$

Table 11 gives the differential power cost due to fuel with a differential heat rate of $209 \mathrm{Btu} / \mathrm{kWh}$, as actually computed for the two detailed heat balances of this study. The differential power cost if the heat rate difference were $593 \mathrm{Btu} / \mathrm{kWh}$ (an arbitrary difference) is also shown in Table 11.

TABLE 11

DIFFERENTIAL POWER COST DUE TO FUEL*

\begin{tabular}{|c|c|c|}
\hline${ }_{c}$ & $\begin{array}{c}\Delta \mathrm{f}_{\mathrm{m}} \\
(\mathrm{mill} / \mathrm{kWh})\end{array}$ & $\begin{array}{c}\Delta \mathrm{f}_{\mathrm{m}} \\
(\mathrm{mill} / \mathrm{kWh}) \\
\left(c / 10^{6} \mathrm{Btu}\right)\end{array}$ \\
\hline 7 & $\Delta \mathrm{H}=209 \mathrm{Btu} / \mathrm{kWh}$ & $\Delta \mathrm{H}=593 \mathrm{Btu} / \mathrm{kWh}$ \\
10 & -0.015 & -0.041 \\
13 & -0.021 & -0.059 \\
16 & -0.027 & -0.077 \\
\hline
\end{tabular}

* Cost values shown are for reheat minus moisture separation

\subsubsection{Combined Differential Power Cost Due to Capital and Fue1}

In Table 12 , the differential power cost due to capital and fuel is combined for a range of moisture separation plant capital price $m$, size exponents $n$, and fuel costs $f_{c}$. The envelope of differential power costs plotted in Figure 24 shows the extreme values for the variables as discussed herein.

Figure 25 plots the envelope of differential power costs with varying differential heat rate. 


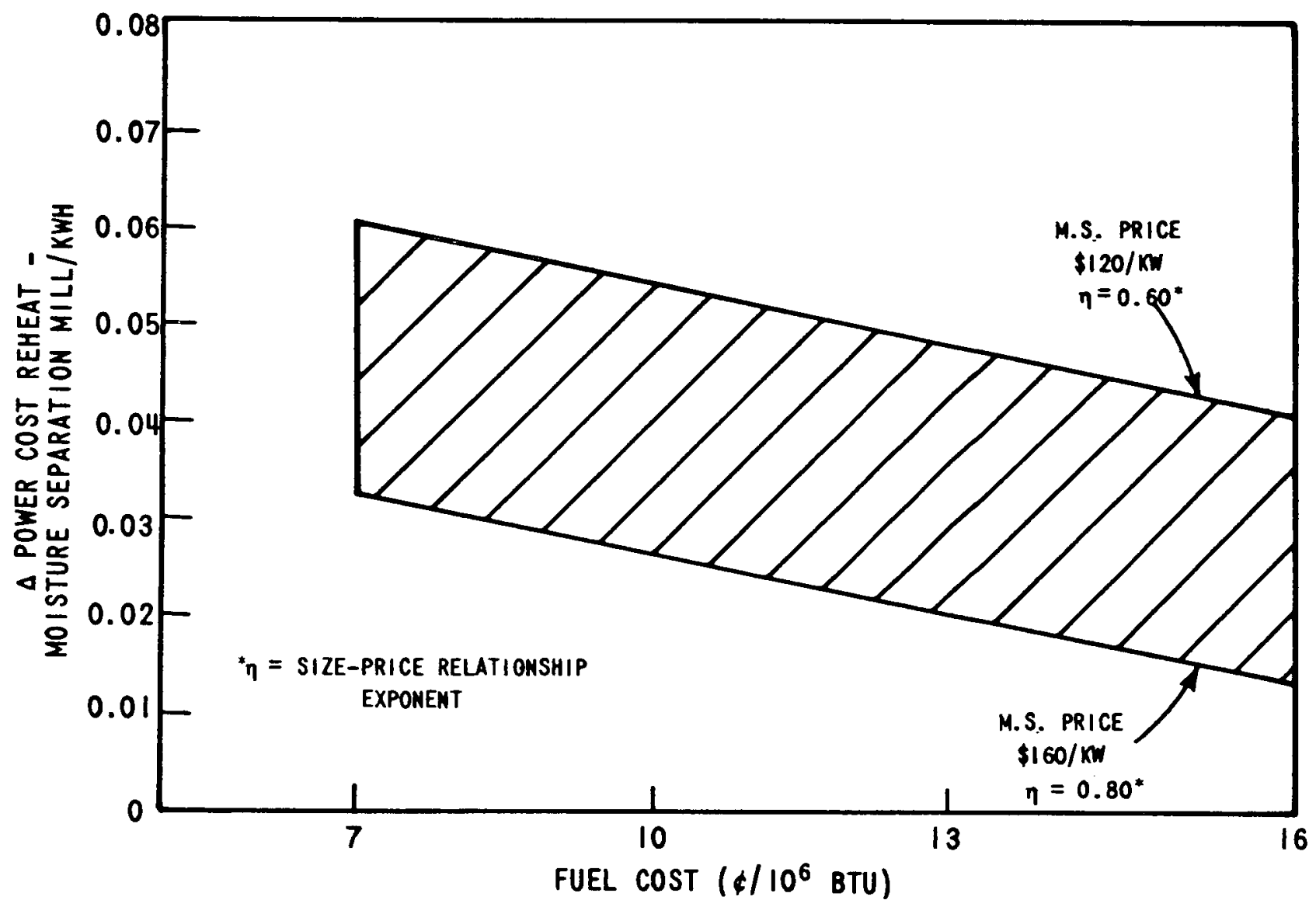

Figure 24. Differential Power Cost Envelope for Sodium Reheat - Moisture Separation 


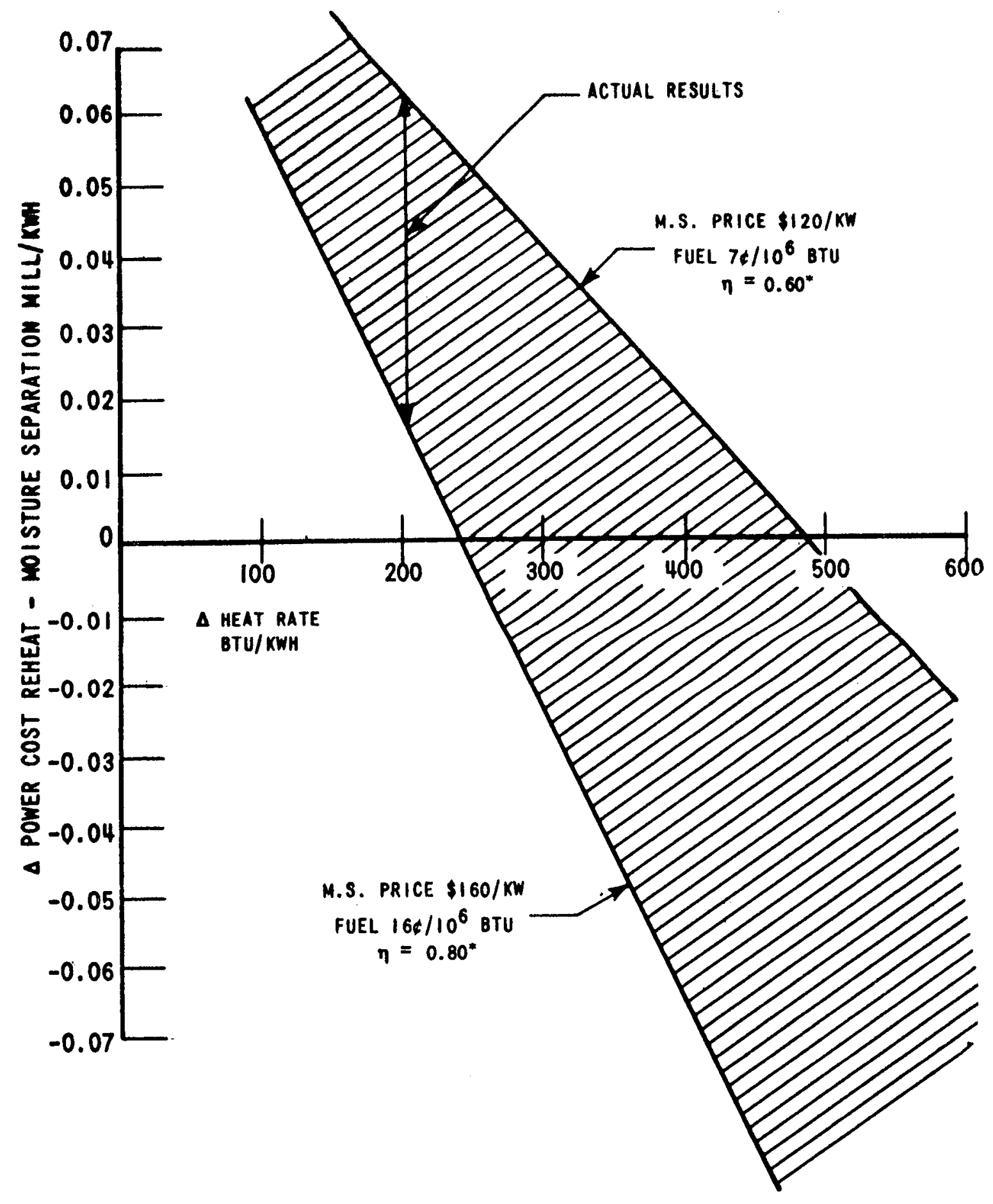

$\because \eta$ SIZE-PRICE RELATIONSHIP EXPONENT

Figure 25. Differential Power Cost Envelope for Sodium ReheatMoisture Separation. as a Function of $\Delta$ Heat Rate 
TABLE 12

DIFFERENTIAL POWER COST FOR REHEAT-MOISTURE SEPARATION PLANT

\begin{tabular}{|c|c|c|c|c|c|}
\hline $\begin{array}{c}\mathrm{m} \\
(\$ / \mathrm{kW})\end{array}$ & $n$ & $\mathrm{f}_{\mathrm{c}}$ & $\Delta \mathrm{f}_{\mathrm{p}}$ & $\Delta \mathrm{f}_{\mathrm{m}}$ & $\begin{array}{c}\Delta \\
\text { Power Cost } \\
(\mathrm{mil1} / \mathrm{kWh})\end{array}$ \\
\hline \multirow[t]{4}{*}{120} & \multirow[t]{4}{*}{0.60} & 7 & 0.075 & -0.015 & 0.060 \\
\hline & & 10 & 0.075 & -0.021 & 0.054 \\
\hline & & 13 & 0.075 & -0.027 & 0.048 \\
\hline & & 16 & 0.075 & -0.033 & 0.042 \\
\hline \multirow[t]{4}{*}{120} & \multirow[t]{4}{*}{0.70} & 7 & 0.068 & -0.015 & 0.053 \\
\hline & & 10 & 0.068 & -0.021 & 0.047 \\
\hline & & 13 & 0.068 & -0.027 & 0.041 \\
\hline & & 16 & 0.068 & -0.033 & 0.035 \\
\hline \multirow[t]{4}{*}{160} & \multirow[t]{4}{*}{0.70} & 7 & 0.055 & -0.015 & 0.040 \\
\hline & & 10 & 0.055 & -0.021 & 0.034 \\
\hline & & 13 & 0.055 & -0.027 & 0.028 \\
\hline & & 16 & 0.055 & -0.033 & 0.022 \\
\hline \multirow[t]{4}{*}{160} & \multirow[t]{4}{*}{0.80} & 7 & 0.047 & -0.015 & 0.032 \\
\hline & & 10 & 0.047 & -0.021 & 0.026 \\
\hline & & 13 & 0.047 & -0.027 & 0.020 \\
\hline & & 16 & 0.047 & -0.033 & 0.014 \\
\hline
\end{tabular}

$\mathrm{H}_{\mathrm{r}}=8281 \mathrm{Btu} / \mathrm{kWh} ; \Delta \mathrm{H}=209 \mathrm{Btu} / \mathrm{kWh} ; \mathrm{R}=6.1\left(\$ 10^{6}\right)$

\subsubsection{Value of $1 \mathrm{Btu} / \mathrm{kWh}$}

In comparing plant economics it is sometimes useful to know the value of a $1 \mathrm{Btu} / \mathrm{kWh}$ heat rate change in terms of equivalent capital. If the capital cost range varies from $\$ 120$ to $\$ 160 / \mathrm{kWh}$ and the fuel cost range varies from 7 to 16 cents per million Btu, then $1 \mathrm{Btu} / \mathrm{kWh}$ heat rate change is worth from $\$ 12,000$ to $\$ 24,000$ capital for a 1000 MWe net plant. 


\section{REFERENCES}

1. K. A. Hub, I. M. Keyfitz, et al., Feasibility Study of Nuclear Steam Supply Using 10,000 MWt Sodium-Cooled Breeder Reactor, ANL 7183, September 1966.

2. H. B. Holz, et a1., 1000 MWe FBR Parametric Study of Secondary SodiumSteam System, NAA-SR-12060.

3. Guide to Nuclear Power Cost Evaluation, TID-7025, March 15, 1962.

4. I. M. Keyfitz, Steam Generator Concept Selection, WARD-22, to be published.

5. Engineering Study for Large Steam-Electric Generating Units and SodiumHeated Steam Generating Islands, United Engineers and Constructors, May 1966. 